\title{
Desindustrialização relativa no Brasil: um balanço por intensidade tecnológica e setores da indústria de transformação no século XXI"
}

\author{
Relative deindustrialization in Brazil: a balance by technological intensity and \\ sectors of the manufacturing industry in the $21^{\text {st }}$ century
}

Arthur Osvaldo Colombo, Ednilson Silva Felipe e Daniel Pereira Sampaio**

\begin{abstract}
Resumo: Este artigo apresenta, sinteticamente, as principais vertentes de pensamento da desindustrialização no Brasil. À luz de seus respectivos escopos teóricos é analisado um conjunto de dados que busca constatar a possível existência de desindustrialização relativa, por intensidade tecnológica, de setores da indústria de transformação nacional. Neste artigo, entende-se por desindustrialização relativa $i$ ) a redução do conteúdo nacional pelo conteúdo importado e ii) substituição do produto final nacional pelo produto final importado. A partir da análise de dados e indicadores conclui-se que existem sinais de que a presença destes tipos de desindustrialização relativa afeta as dinâmicas internas e externas e atingem, principalmente, setores de média-alta e alta intensidade tecnológica. Não obstante, argumenta-se que o processo de desindustrialização no Brasil possui característica dinâmica, complexa e de multiformato.
\end{abstract}

Palavras-chave: Desindustrialização. Indústria de Transformação. Economia Brasileira. Desempenho Setorial

\begin{abstract}
This article summarizes the main aspects of deindustrialization in Brazil. In the light of their respective theoretical scopes, a set of data was analyzed that seeks to verify the possible existence of relative deindustrialization, by technological intensity, of some sectors of the national manufacturing industry. In this article, relative deindustrialization means: i) reduction of national content for imported content and ii) replacement of the final national product for final imported product. From the data and indicators analysis, it can be concluded that there are signs that the presence of these types of deindustrialization affects internal and external dynamics and, mainly, affect sectors of medium-high and high technological intensity. Notwithstanding that the
\end{abstract}

\footnotetext{
* Submissão: 05/05/2020 | Aprovação: 18/10/2020 | DOI: 10.5380/re.v42i79.72957.73525

** Respectivamente: (1) Doutorando em Economia, Programa de Pós-Graduação em Economia da Indústria e da Tecnologia, Universidade Federal do Rio de Janeiro (UFRJ) | ORCID: 0000-0002-1128-9140 |E-mail: arthur_colombao@hotmail.com | (2) Programa de Pós-Graduação em Engenharia e Desenvolvimento Sustentável, Departamento de Economia, Universidade Federal do Espírito Santo (UFES) | ORCID: 00000002-4147-2069 | E-mail: ednilsonfelipe.ufes@gmail.com | (3) Programa de Pós-Graduação em Política Social, Departamento de Economia, Universidade Federal do Espírito Santo (UFES) | ORCID: 0000-00026130-2753 | E-mail: danielpereirasampaio@gmail.com | O trabalho contou com financiamento da FAPES/Proapex.
}

Esta publicação está licenciada sob os termos de

Creative Commons Atribuição-Não Comercial 4.0 Internacional 
process of desindustriaization in Brazil has a dynamic, a complex, and multiformat characteristics.

Keywords: Deindustrialization. Manufacturing Industry. Brazilian Economy. Industry Studies

JEL: L60. L16. O14. O32. O54 


\section{Introdução}

O principal objetivo deste artigo é apresentar as principais vertentes de pensamento que estudam a desindustrialização no Brasil demonstrando, em cada uma das perspectivas, quais são as principais fontes do processo, assim como as recomendações para a superação desta condição. Não obstante, foram observados possíveis sinais de desindustrialização relativa ao longo de alguns setores que compõem a indústria de transformação brasileira. Para a análise, os setores foram divididos de acordo com sua intensidade tecnológica ${ }^{1}$ e as análises dos resultados foram embasadas nos respectivos escopos teóricos das vertentes de pensamento apresentadas na primeira seção.

Os dados e indicadores utilizados no presente estudo são os disponibilizados pela Confederação Nacional da Indústria $(\mathrm{CNI})^{2}$, pelo Instituto Brasileiro de Geografia e Estatística (IBGE) e pelo Ministério do Desenvolvimento, Indústria e Comércio Exterior (MDIC) ${ }^{3}$. Foi utilizada a tipologia por intensidade tecnológica da Organização para a Cooperação e Desenvolvimento Econômico (OCDE), quais sejam: $i)$ alta, $i i)$ média-alta, $i i i)$ média-baixa e $i v$ ) baixa intensidade tecnológica.

Segundo Sampaio (2015), a desindustrialização pode ser entendida como absoluta ou relativa. A desindustrialização absoluta é o grau mais severo, na qual se observa o fechamento de unidades industriais. A desindustrialização relativa pode ser dividida em três formatos: $i$ ) aumento do gap tecnológico; ii) redução do conteúdo nacional e aumento do conteúdo importado (ou quebra de elos em cadeias produtivas); e iii) substituição do produto final nacional pelo produto final importado (Sampaio, 2015). Em que pese a importância do diagnóstico dos distintos formatos da desindustrialização, neste artigo serão analisados os casos ii) e iii) da desindustrialização relativa. Apesar de parte dos dados e indicadores estarem compreendidos no período de 2003-20174, o foco da análise se dará após 2008.

\footnotetext{
${ }^{1}$ Alguns setores não possuem os dados disponíveis na CNI e devido a isso não serão analisados. Foram realizados ajustes nos demais dados e indicadores para compatibilizar as informações.

${ }^{2}$ Os dados da CNI têm como referência a CNAE 2.0 a 2 dígitos. Os dados utilizados são principalmente os que se referem ao comércio exterior.

${ }^{3}$ Após a reforma ministerial de 2019, foi alterado para Secretaria de Comércio Exterior do Ministério da Economia.

${ }^{4}$ A CNI disponibiliza os indicadores de coeficiente de insumos importados e de coeficiente de penetração das importações a preços constantes (que serão os principais dados para demonstrar sinais de desindustrialização relativa) no período de 2003 a 2017. Devido a isso, a análise destes indicadores se restringiu a este recorte temporal. No entanto, a análise dos demais indicadores ficou restrita no pós-2008, justamente para avaliar o comportamento da indústria brasileira após a grave crise internacional.
} 
O presente trabalho está estruturado em três seções além desta introdução e da conclusão. Na primeira seção, como já informado, são apresentadas algumas vertentes de pensamento sobre a desindustrialização no Brasil. Na segunda, são analisados dados e indicadores do Grupo 1, que perfazem os setores de baixa e média-baixa intensidade tecnológica, e, por fim, na terceira seção são analisados dados e indicadores do Grupo 2, que perfazem os setores de média-alta e alta intensidade tecnológica. Segue-se, após, as considerações finais.

\section{Desindustrialização e suas vertentes de pensamento}

Nesta primeira seção, serão apresentadas as vertentes de pensamento sobre a desindustrialização no Brasil, quais sejam, ortodoxos, novo-desenvolvimentistas, estruturalistas e industrialistas. Elas buscam explicar o porquê da desindustrialização e indicar possíveis saídas para a reversão dela. Para a divisão dos autores, foi considerado o conjunto de suas obras (artigos, livros e entrevistas) no qual são analisadas e apresentadas suas concepções sobre a temática. Como critérios para classificação dos autores, foram considerados os seguintes:

i) Os principais motivos pelo qual o processo ocorre no Brasil. Isto é, quais são as fontes da desindustrialização no país.

ii) As recomendações para a alteração do atual quadro que configura a desindustrialização. Ou seja, quais seriam as estratégias a serem adotadas para evitar o desmantelamento da indústria de transformação nacional no longo prazo.

Cada uma das vertentes encara como correta a interpretação de que o Brasil passa por um processo de desindustrialização. No entanto, cada vertente apresenta constatações distintas do processo, isto é, cada uma apresenta diferentes origens do fenômeno e, por conseguinte, distintos caminhos para uma possível reversão.

\subsection{Ortodoxos}

Partindo do modelo de Solow, para essa vertente a indústria não apresenta vantagens em relação aos outros setores. Portanto, não é um problema grave a manufatura deixar de ser o motor do crescimento da economia. Assim, a partir de modelos neoclássicos de crescimento, a desindustrialização se torna irrelevante, pois não impacta no crescimento de longo prazo (Oreiro; Feijó, 2010). Alguns dos 
principais integrantes da vertente ortodoxa são: Regis Bonelli ${ }^{5}$, Edmar Bacha, Samuel Pessoa e Silvia Matos. Inobstante, para autores dessa vertente, o Brasil passou por "doença soviética" entre as décadas de 1970 e 1980, ou seja, a manufatura tinha, comparativamente à média mundial, um sobrepeso no Produto Interno Bruto (PIB) e, a partir da década de 1990, convergiu para um padrão em relação à média mundial (Bonelli; Pessoa; Matos, 2013).

Segundo esta vertente, embora a abertura comercial da década de 1990 e a taxa de câmbio sobrevalorizada tenham prejudicado a indústria nacional no curto prazo, tais medidas seriam benéficas no longo prazo, estimulando o desenvolvimento manufatureiro. Assim, as reformas pró-mercado e a consolidação de uma política macroeconômica austera estimularam a indústria nacional rumo a “integração competitiva", induzindo ganhos de produtividade e modernização do parque industrial. Para atenuar o processo de desindustrialização, recomenda-se nova rodada de abertura comercial para aumentar a competitividade, devido ao acesso a melhores bens e fatores de produção como capital, consumo intermediários, tecnologia e trabalho, proporcionando, assim, uma alocação mais eficiente de recursos. Desta forma, aumentar a quantidade de insumos importados ou importar bens de capital, por exemplo, não seria algo prejudicial para a manufatura nacional.

Outra medida é a redução da intervenção estatal, sendo que sua função se limitaria ao saneamento fiscal e controlar a inflação em patamares baixos. Essas medidas trariam impactos positivos nas expectativas dos agentes econômicos, propiciando condições para atração de investimentos. Além disso, estão inclusas as "reformas microeconômicas", como a redução da carga tributária e simplificação no sistema tributário, desregulamentação do trabalho, entre outras. Nessa vertente, em suma, o baixo crescimento da produtividade no Brasil se deve às ineficiências alocativas geradas a partir da intervenção estatal (Bonelli, 2005; Bacha, Bonelli, 2005; Schwartsman, 2009; Bonelli; Pessoa; Matos, 2013; Bacha, Bolle (Org.). 2013).

\footnotetext{
${ }^{5}$ In memorian (2017).
} 


\subsection{Novo desenvolvimentistas}

Dentre os principais pensadores do novo desenvolvimentismo, podemos citar Bresser Pereira, José Oreiro e Nelson Marconi. O novo desenvolvimentismo se apresenta como um pensamento avesso ao liberalismo econômico de origem neoclássica, pois, segundo esta concepção, ela é incompatível com o desenvolvimento de uma economia de renda média, como a brasileira.

Como base central, esta abordagem tem como referência um modelo de crescimento do tipo export-led, no qual o principal motor da economia seria as exportações, particularmente a de manufaturados, auxiliando, como consequência, a adoção de progresso tecnológico na indústria nacional (Oreiro, 2016)

A taxa de câmbio é a principal variável para o sucesso deste modelo e, sendo assim, o governo deve mantê-la em um nível que torne a indústria competitiva no cenário internacional. Ou seja, medidas de política econômica devem ser constantemente tomadas para que uma taxa real de câmbio competitiva possa ser mantida, no médio e no longo prazo, de forma a incentivar a indústria de transformação. Além disso, o governo deve apresentar suas contas saneadas de maneira intertemporal, apresentando, no longo prazo, um déficit fiscal zero. Assim, em momentos em que a economia se encontra em crise, o governo pode atuar de maneira ativa através da expansão dos gastos públicos para impulsionar a retomada do crescimento e diminuir a amplitude do ciclo econômico (política fiscal expansionista). Já em momentos de crescimento, obter superávits, de um modo que, no longo prazo, a condição de déficit fiscal igual a zero seja satisfeita. Com isto, segundo esta vertente, é criada uma situação na qual é possível o Estado investir de maneira sustentável (Bresser-Pereira, 2018).

O salário também é uma variável que apresenta importância. A política salarial deve ser orientada de maneira que os salários sejam corrigidos pela inflação, acrescidos da produtividade do trabalho. Isto proporcionaria (junto com a política fiscal citada anteriormente) um ambiente macroeconômico marcado pela estabilidade de preços e favorável à distribuição funcional da renda no longo prazo, abrindo espaço para o Banco Central praticar uma política monetária de juros baixos, estimulando, também no longo prazo, o crescimento econômico (BresserPereira, 2018).

A partir disso, é possível concluir que a alocação dos cinco preços macroeconômicos (câmbio, juros, fiscal, salários e inflação) no patamar 
considerado ideal apresenta importância para o novo desenvolvimentismo. A ausência do alinhamento dos cincos preços macroeconômicos impede o desenvolvimento econômico e não permite a reversão do atual quadro de desindustrialização (Bresser-Pereira, 2018).

Segundo esta vertente, o Brasil passa pelo processo de desindustrialização por causa da "doença holandesa", fenômeno debatido na década de 1960 na Holanda, onde uma imensa reserva de gás natural foi descoberta. A exportação do gás natural bem apreciou a taxa de câmbio e essa apreciação, por sua vez, prejudicou a manufatura.

Mas vale dizer que os formulares do novo desenvolvimentismo afirmam que essas proposições não são compatíveis com o crescimento estimulado através de déficit público, protecionismo e o antigo modelo cepalino de substituição de importações. Tais modelos não têm serventia ou até mesmo são equivocados para incentivar a indústria de transformação brasileira, como expressa Oreiro (2016):

[...] dessa forma o modelo de desenvolvimento que esses países adotaram na fase inicial do seu processo de industrialização, o qual era baseado na substituição de importações se esgotou no início da década de 1970 [...] O novo desenvolvimentismo não é protecionista. Como a fase de indústria infante foi superada, as empresas dos países de renda média devem ser competitivas em todos os setores industriais aos que se dedicarem, devendo inclusive ser competitivas o suficiente para exportar (Oreiro, 2016, p. 149).

Para essa vertente, a doença holandesa é definida como uma falha de mercado que atinge praticamente todas as nações que estão em fase de desenvolvimento (Bresser-Pereira; Marconi; Oreiro, 2015; Oreiro, 2016; Silveira; Angeli; Salomão, 2019). Portanto, o esforço deve ocorrer na direção de traçar uma estratégia nacional de desenvolvimento que contemple ajuste nas variáveis macroeconômicas com esforços voltados para a indústria, como foi o processo de desenvolvimento asiático, como o da Coreia do Sul. Políticas recomendadas são a depreciação da taxa de câmbio e políticas para neutralização da doença holandesa (por exemplo, imposto para bens causadores da doença holandesa).

Resumidamente, podemos denotar que, segundo a vertente do novo desenvolvimentismo, a principal fonte de desindustrialização no Brasil é a doença holandesa. A partir disso, sua principal recomendação para que o país supere esta condição e a indústria de transformação nacional retome a competitividade, a neutralização desta falha de mercado é um fator essencial. O ajustamento dos cinco 
preços macroeconômicos é recomendação fulcral para a superação da condição de desindustrialização. Não obstante, embora seja uma vertente de pensamento essencialmente heterodoxa, estão presentes alguns pontos que predominam na ortodoxia como otimização, equilíbrio orçamentário e maior nível de abertura comercial. As duas vertentes que serão apresentadas a seguir não apresentam em seu escopo teórico estes pontos que, ao menos marginalmente, são similares a vertente ortodoxa.

\subsection{Estruturalistas}

Essa vertente conta, principalmente, com pesquisadores da Universidade Estadual de Campinas (Unicamp). Os professores Wilson Cano ${ }^{6}$ e Ricardo Carneiro são dois dos principais integrantes desta vertente. A análise da formação e desenvolvimento das estruturas econômicas é o método utilizado. O subdesenvolvimento não se apresenta apenas como um estágio no desenvolvimento capitalista, mas sim como processo histórico que se reproduz no tempo e no espaço (Furtado, 1998). Fatos históricos, a partir da década de 1980, explicam o início e continuidade do processo de desindustrialização no Brasil. O primeiro foi a crise da dívida externa, no início da década de 1980, que esgotou o padrão de financiamento do modelo de Industrialização por Substituição de Importações (ISI). Na década de 1990, houve implementação das políticas neoliberais e o Plano Real. $\mathrm{O}$ período ficou marcado por políticas macroeconômicas - que conjugaram juros elevados, câmbio sobrevalorizado e restrições fiscais - juntamente com abertura comercial, financeira e privatizações que foram realizadas de forma rápida e não planejada. Assim, a saída do Estado como agente coordenador e promotor do desenvolvimento e sua substituição pelos mercados é uma das causas da desindustrialização.

Percebe-se, assim, que as medidas pós ISI são "anti-industriais" e contribuíram para o processo de desindustrialização precoce (Carneiro, 2008; Cano, 2014). Cano (2014) recomenda que o Brasil deveria abandonar a Organização Mundial de Comercio (OMC) justamente para que estratégias de cunho protecionais pudessem ser adotadas:

As restrições impostas sobre o câmbio, juro, crédito e finança pública impedem ou causam fortes restrições de fato ao manejo da política

\footnotetext{
${ }^{6}$ In memorian (2020).
} 
macroeconômica de desenvolvimento que efetivamente atenda os interesses desses países. É uma verdadeira "camisa de força" que restringe muito o manejo da política econômica nacional. E é com essa herança perversa que entramos no século XXI. Conseguimos nos livrar da ALCA em 2005, mas já havíamos entregue nossa política comercial, quando em 1994 aceitamos o jogo da OMC. A ALCA nos obrigou a muito trabalho político e diplomático, dadas as dificuldades em dizer não aos EUA, mas essa proposta, tinha apenas a fachada de "livre comércio", pois continha cláusulas comprometedoras com várias questões delicadas: comércio de serviços e eletrônico; compras governamentais; acordo de investimentos e de propriedade intelectual (Cano, 2014, p. 13).

Assim, um balanço entre a vertente novo desenvolvimentista e a estruturalista remete a uma divergência teórica entre elas. Para os novos desenvolvimentistas práticas protecionistas não seriam mais necessárias, porém para a vertente estruturalista práticas protecionistas são fundamentais para o desenvolvimento da indústria nacional sendo fundamental para sua retomada.

Para alterar esta trajetória, sugere-se rompimento com os modelos de política macroeconômica neoliberal, retomada de políticas de cunho protecionista, e retomada do fortalecimento de elos nas cadeias produtivas, bem como a incorporação de novos setores industriais.

\subsection{Industrialistas}

Nesta vertente repetem-se vários fatores desencadeadores da desindustrialização, tais como as taxas de câmbio e juros. Além disso, enfatiza-se a dinâmica da inovação e a concorrência internacional, principalmente levando em consideração a relevância da China na produção e exportação de bens manufaturados. Ressalta-se a importância da fronteira tecnológica, tanto em produtos, processos, mercados e matérias-primas, com o objetivo de aumentar a produtividade da indústria de transformação. A preocupação desta vertente volta-se, assim, para a inovação. $O$ processo de desindustrialização no Brasil ocorre essencialmente devido a incapacidade da indústria brasileira, principalmente após a década de 1980, de acompanhar as inovações e os avanços produtivos que as indústrias tiveram no plano global (Kupfer, 2009; Diniz, 2017; Sarti; Hiratuka, 2018). Dentre os principais autores desta vertente podemos citar Clélio Campolina Diniz, David $\mathrm{Kupfer}^{7}$, Mariano Laplane, Fernando Sarti, Célio Hiratuka.

\footnotetext{
${ }^{7}$ In memorian (2020).
} 
As revoluções industriais alteram padrões tecnológicos vigentes, sendo a corrida pela fronteira tecnológica entendida como vital para o desenvolvimento econômico num cenário de concorrência global. Assim, há hierarquias na dinâmica da produção, sendo que as lideranças são denominadas forging ahead. É natural que outras nações busquem ingressar nestas novas dinâmicas produtivas ocasionada pelos saltos tecnológicos. Assim, o emparelhamento é denominado catching up, enquanto o insucesso é denominado falling behind. Portanto, o Brasil se enquadra em falling behind desde a década de 1980, sendo este um dos fatores que contribuem para a desindustrialização.

A recomendação para superação da desindustrialização é a retomada do processo de catching up através de uma política industrial com foco na inovação. Para isso, o Estado deve ser ativo, num planejamento que possibilite direcionamento de recursos voltados para pesquisa e desenvolvimento (Arend; Fonseca, 2012).

A indústria nacional, por meio de sucessivos ajustes defensivos, acabou buscando corte de despesas, o que levou ao desadensamento de cadeias produtivas e redução de sua diversificação setorial, o que tende a reduzir os investimentos em ciência, tecnologia e inovação. Assim, inovações da indústria doméstica tendem a ocorrer em menor frequência. Esses fatores ajudam a explicar a perda de espaço da indústria brasileira no cenário mundial (Kupfer, 2016; Diniz, 2017; Sarti; Hiratuka, 2018). Em suma, a estrutura industrial aprofunda seu atraso:

O problema é maior ainda porque está havendo transformações pesadas
do papel da tecnologia e da inovação e também das formas de
organização internacional da produção na competição global. Estamos
em um mundo em rápido movimento e o Brasil parece não conseguir
acompanhar. O resultado é inevitável: a defasagem tecnológica da
economia está aumentando. (...) É mais amplo do que exclusivamente
essa dimensão macroeconômica. É algo num plano estrutural, na
tecnologia num sentido amplo ligada aos produtos que circulam na
economia, aos processos que elaboram esses produtos, à organização
produtiva por trás desse sistema industrial (...) (Kupfer, 2015, s.p.).

Sarti e Harituka (2011) entendem que o mais importante é traçar um novo plano para o futuro da indústria nacional de médio e longo prazo:

[...] o desafio da política de desenvolvimento industrial será promover mudanças estruturais: a) ampliação da capacidade de produção, de inovação, de diferenciação e de agregação de valor; b) modernização e ampliação da infraestrutura; c) reestruturação patrimonial e consolidação de empresas líderes e de grupos econômicos para a 
ampliação da escala empresarial; d) maior integração dos sistemas de produção, distribuição e comercialização; e) ampliação e melhoria das funções corporativas das filiais de empresas estrangeiras no âmbito da cadeia global de valor; f) maior inserção exportadora em setores de maior conteúdo tecnológico e maior agregação de valor; e g) ampliação do grau de internacionalização produtiva das empresas nacionais (Sarti; Harituka, 2011, p. 30).

Portanto, é possível notar que o atraso tecnológico entre as unidades industriais brasileiras e a fronteira tecnológica é uma das principais fontes de desindustrialização. Este ponto não é abordado sistematicamente nas vertentes antes mencionadas e aqui o gap tecnológico aparece como o principal determinante da desindustrialização no Brasil. As recomendações para a superação desta situação, além da utilização de políticas macroeconômicas alinhadas à indústria, são a elaboração e execução de planos com foco em pesquisa e inovação, justamente, com o objetivo de diminuir o gap tecnológico.

Não obstante, vale ressaltar que políticas industriais com ênfase em pesquisa e desenvolvimento são, na grande maioria das vezes, extremamente onerosas e em muitos casos apresentam longo prazo de maturação. Portanto, a ideia de equilíbrio orçamentário apresentado pela vertente do novo desenvolvimentismo perde relevância dentre as proposições elencadas pela vertente industrialista ${ }^{8}$

Abaixo segue o Quadro 1, que faz uma síntese das vertentes apresentadas. Recorda-se que, em alguma medida, alguns pontos podem convergir entre elas, porém, como já visto, apresentam suas particularidades:

\footnotetext{
${ }^{8}$ Schumpeter aponta que a inovação apresenta caráter disruptivo do sistema econômico, assim se quebra a noção de equilíbrio.
} 

Quadro 1 - Resumo das vertentes sobre o processo de desindustrialização no
Brasil

\begin{tabular}{|c|c|c|c|}
\hline Vertente & $\begin{array}{c}\text { Principais }^{9} \\
\text { Autores }\end{array}$ & $\begin{array}{l}\text { Motivos } \\
\text { (Causas) }\end{array}$ & Resolução(es) \\
\hline Ortodoxa & $\begin{array}{c}\text { Regis Bonelli } \\
\text { Samuel Pessoa } \\
\text { Silvia Matos } \\
\end{array}$ & $\begin{array}{c}\text { Abertura } \\
\text { Comercial } \\
\text { Insuficiente }\end{array}$ & $\begin{array}{l}\text { Nova rodada de abertura } \\
\text { comercial buscando o } \\
\text { aumento de produtividade }\end{array}$ \\
\hline $\begin{array}{c}\text { Novo } \\
\text { Desenvolvimentismo }\end{array}$ & $\begin{array}{l}\text { Bresser Pereira } \\
\text { José Oreiro } \\
\text { Nelson Marconi }\end{array}$ & $\begin{array}{l}\text { Doença } \\
\text { Holandesa }\end{array}$ & $\begin{array}{l}\text { Neutralização da doença } \\
\text { holandesa através da } \\
\text { desvalorização cambial } \\
\text { (Câmbio Industrial) }\end{array}$ \\
\hline Estruturalista & $\begin{array}{c}\text { Wilson Cano } \\
\text { Ricardo Carneiro }\end{array}$ & $\begin{array}{l}\text { Abertura } \\
\text { Comercial } \\
\text { Crise da } \\
\text { Dívida } \\
\end{array}$ & $\begin{array}{l}\text { Política industrial forte, } \\
\text { aumento significativo do } \\
\text { investimento estatal e } \\
\text { mudança radical do } \\
\text { ambiente macroeconômico. }\end{array}$ \\
\hline Industrialistas & $\begin{array}{l}\text { David Kupfer } \\
\text { Fernando Sarti } \\
\text { Célio Hiratuka } \\
\text { Clélio C. Diniz } \\
\text { Mariano Laplane }\end{array}$ & \begin{tabular}{|} 
Ausência de \\
Coordenação \\
entre \\
iniciativa \\
pública e \\
privada \\
Gap \\
tecnológico \\
Faling \\
Behind
\end{tabular} & $\begin{array}{l}\text { Política industrial forte } \\
\text { com foco na inovação, } \\
\text { retomada do } \\
\text { processo de catching up, } \\
\text { busca por modernização de } \\
\text { bens de capital }\end{array}$ \\
\hline
\end{tabular}

Fonte: Colombo, Felipe e Sampaio (2019, p. 18).

As subseções apresentadas acima analisaram as principais vertentes de pensamento no Brasil que se dispuseram a discutir sobre o processo de desindustrialização. Foram apresentados pensamentos de alguns de seus principais autores, quais as causas que levam o país a passar por um processo de desindustrialização, e quais seriam as possíveis resoluções para este problema.

Nas próximas seções serão apresentados os dados de alguns setores que compõem a indústria de transformação brasileira. Estes setores foram divididos de acordo com suas respectivas intensidades tecnológicas. A análise dos dados e

\footnotetext{
${ }^{9}$ No quadro foram listados apenas os autores que tiveram seus trabalhos utilizados como referência neste artigo, todavia, estas vertentes contam com outros autores que também apresentam pesquisas de destaque na temática da desindustrialização. Para uma análise mais detalhada sobre as vertentes de pensamento sobre a desindustrialização no Brasil ver Colombo, Felipe e Sampaio (2019).
} 
indicadores que foi elaborada está embasada nas concepções das vertentes da desindustrialização que foram apresentadas nesta seção.

\section{Grupo 1: baixa e média-baixa intensidade tecnológica}

Nesta seção e na próxima, o objetivo será analisar por intensidade tecnológica da OCDE e por setor se há desindustrialização relativa por $i$ ) quebra elos em cadeias produtivas e ii) substituição do produto final pelo importado. Esta seção tratará do Grupo 1 que engloba setores que pertencem à tipologia de baixa e média-baixa intensidade tecnológica.

\subsection{Baixa intensidade tecnológica (BIT)}

O coeficiente de insumos industriais importados (CIP) mede a participação dos insumos industriais importados no total de insumos industriais adquiridos pela indústria. Quanto maior o coeficiente, maior é a utilização de insumos importados pela indústria (CNI, 2016). O coeficiente de insumos importados do setor $\mathrm{k}$ é definido como:

$$
C I I_{k}=\frac{I M_{k}}{I_{k}}
$$

Onde:

$I M_{k}$ é o valor dos insumos industriais importados pelo setor $\mathrm{k}$;

$I_{k}$ é o valor total de insumos industriais utilizados pelo setor $\mathrm{k}$

O gráfico 1 demonstra a evolução do CIP na indústria de transformação no período compreendido entre 2003-2017 para os setores de baixa intensidade tecnológica, a preços constantes. 


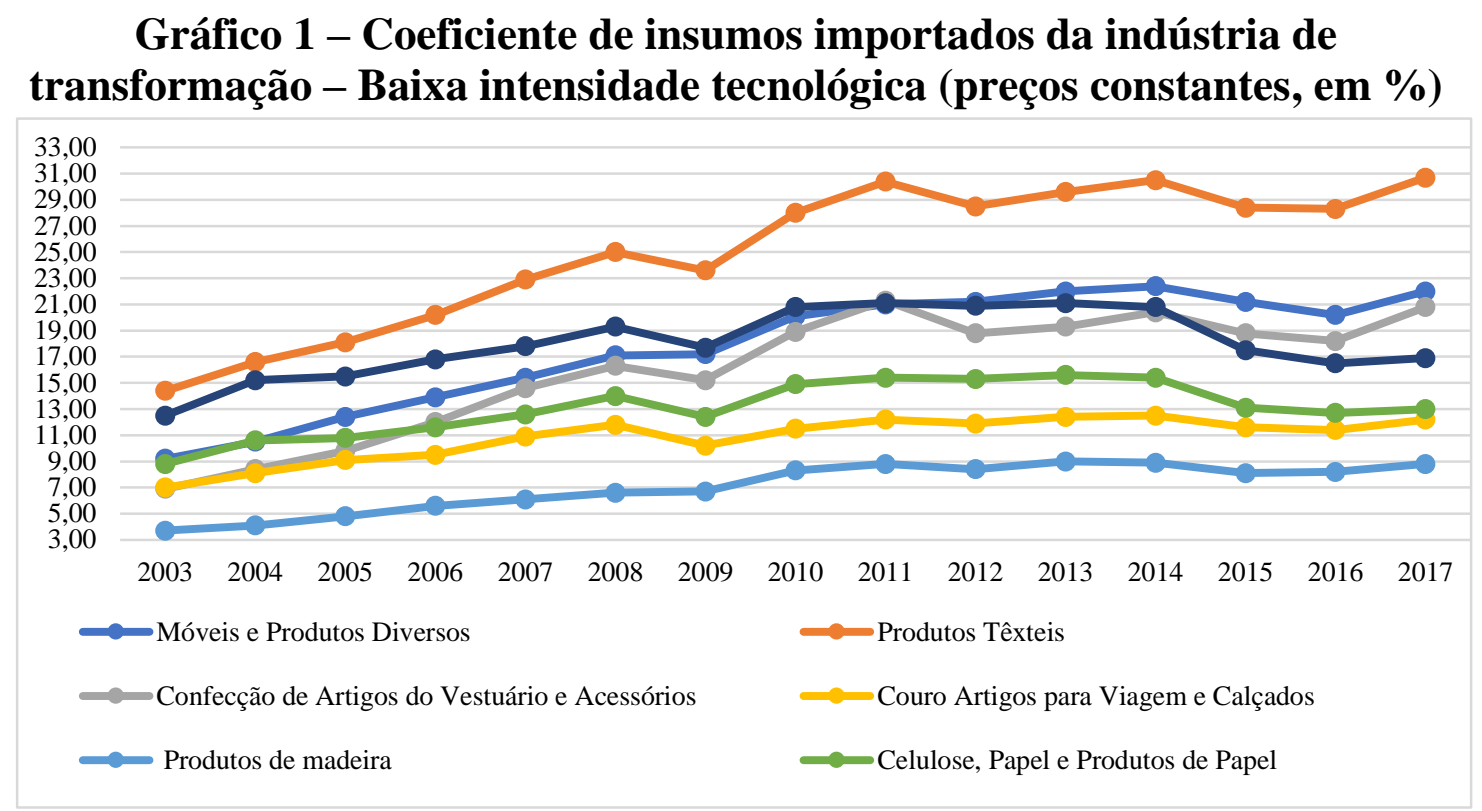

Fonte: CNI. Elaboração própria.

No gráfico 1, observa-se que todos os setores tiveram elevação no CIP, indicador utilizado para auferir também se houve quebra de elos em cadeias produtivas. Móveis e produtos diversos teve elevação do CIP de 9,2\% em 2003 para 22\% em 2017; produtos têxteis passou de $14,4 \%$ para $30,7 \%$, respectivamente; confecção de artigos do vestuário e acessórios de 6,9\% para $20,8 \%$; couro, artigos para viagem e calçados de $7 \%$ para $12 \%$; produtos de madeira de $3,7 \%$ para $8,8 \%$; celulose, papel e produtos de papel de $8,8 \%$ para $13 \%$; e, por fim, impressão e produtos de gravações de $12,5 \%$ para $16,9 \%$. Contata-se que os setores de baixa intensidade tecnológica passaram por um processo de desadensamento de cadeias produtivas. A elevação do CIP diminui o fornecimento, nos elos produtivos, de produtos nacionais, promovendo uma das faces da desindustrialização, ainda que a produção física final possa continuar sem alterações. Contudo, cabe aprofundar a análise, considerando a evolução da produção física (tabela 1). 
Tabela 1 - Variação da produção física industrial - Baixa intensidade tecnológica (em \%)

\begin{tabular}{c|c|c|c|c|c|c|c}
\hline Anos & $\begin{array}{c}\text { Móveis e } \\
\text { Produtos } \\
\text { diversos }\end{array}$ & $\begin{array}{c}\text { Produtos } \\
\text { têxteis }\end{array}$ & $\begin{array}{c}\text { Confecção de } \\
\text { artigos do } \\
\text { vestuário e } \\
\text { acessórios }\end{array}$ & $\begin{array}{c}\text { Couro, } \\
\text { artigos } \\
\text { para } \\
\text { viagem e } \\
\text { calçados }\end{array}$ & $\begin{array}{c}\text { Produtos } \\
\text { de madeira }\end{array}$ & $\begin{array}{c}\text { Celulose, } \\
\text { papel e } \\
\text { produtos } \\
\text { de papel }\end{array}$ & $\begin{array}{c}\text { Impressão e } \\
\text { reprodução de } \\
\text { gravações }\end{array}$ \\
\hline 2008 & $-2,6$ & $-3,1$ & 5,1 & $-6,8$ & $-10,2$ & 5,1 & - \\
\hline 2009 & -5 & -7 & $-6,3$ & $-8,6$ & $-17,7$ & $-1,8$ & - \\
\hline 2010 & 12,3 & 4,3 & 7,5 & 6,7 & 16,3 & 4,5 & - \\
\hline 2011 & 1,6 & -16 & $-3,7$ & $-10,5$ & $-0,5$ & 1,4 & - \\
\hline 2012 & 5,7 & $-4,7$ & $-8,7$ & $-3,6$ & 8,8 & 1,5 & - \\
\hline 2013 & 1,7 & 0,2 & $-0,5$ & 4,3 & 2 & $-0,6$ & $-4,5$ \\
\hline 2014 & $-7,3$ & $-6,6$ & -3 & $-4,2$ & $-2,6$ & -1 & $-3,8$ \\
\hline 2015 & $-13,8$ & -15 & $-11,7$ & $-7,7$ & $-4,6$ & $-0,6$ & $-18,9$ \\
\hline 2016 & $-10,1$ & $-4,6$ & $-5,8$ & $-1,3$ & 1,3 & 2,3 & $-11,1$ \\
\hline 2017 & 4,5 & 5,6 & 3,5 & 0,8 & 1,8 & 3,3 & $-10,2$ \\
\hline Taxa & $-1,59$ & $-4,93$ & $-2,54$ & $-3,24$ & $-0,94$ & 1,38 & $-9,87$ \\
\hline Média & & & &
\end{tabular}

Fonte: IBGE (PIM-PF). Elaboração própria.

A partir da tabela 1 observa-se que todos os setores de BIT apresentam taxas de variação médias negativas, exceto celulose, papel e produtos de papel. Móveis, produtos diversos e o de produtos de madeira apresentaram resultados negativos em 6 anos; produtos têxteis, confecção de artigos do vestuário e couro, bem como o de artigos para viagem e calçados em 8 anos; celulose, papel e produtos de papel em 4 anos; o setor de impressão e reprodução de gravações apresentaram resultado negativo em todos os anos com dados disponíveis ${ }^{10}$. A partir da análise da produção física, é possível elaborar uma crítica à ortodoxia. Não foi apresentada uma contrapartida na produção física concomitante ao aumento das importações de insumos. Além de parte dos insumos terem sido adquiridos no exterior, a produção física interna diminuiu, o que sugere um cenário preocupante.

Como ilustração da dinâmica da tipologia, destaca-se o setor têxtil nacional. Segundo Almeida (2014), 97,5\% do destino da produção destina-se ao mercado interno. O Presidente da Associação Brasileira da Indústria Têxtil (ABIT), Rafael Cervone, apontou razões da fragilidade no setor têxtil:

\footnotetext{
${ }^{10}$ Dados disponíveis a partir de 2013.
} 
[...] o encarecimento dos custos de produção, com destaque para energia elétrica e tributação, além da concorrência com os chineses, tem levado os empresários do setor a mudar de estratégia para manter as atividades [...] abrir mais os negócios no mercado externo é uma das estratégias para estimular a produção [...] (Moreira, 2015, s.p.).

Percebe-se, desse modo, que devido à dificuldade de produção no mercado nacional, uma estratégia empresarial adotada foi migrar parte ou total da produção ao exterior, fator que proporciona a fragilização de elos ao longo da cadeia produtiva. Por outro lado, a análise da dinâmica do setor externo considera dados das exportações, importações e saldo da balança comercial. Vale averiguar se o aumento das importações foi correspondido com um aumento nas exportações. Ou seja:

Quando o coeficiente de insumos e componentes importados aumenta sem uma contrapartida nas exportações, podem-se fragilizar elos produtivos, reduzir os encadeamentos intersetoriais e limitar o desenvolvimento tecnológico, cada vez mais conduzido pelos fornecedores dos componentes principais. Isso pode agravar a desindustrialização (...) (Morceiro, 2018, p. 44).

\section{Gráfico 2 - Exportações, importações e saldo da balança comercial - Baixa intensidade tecnológica (US\$ milhões)}

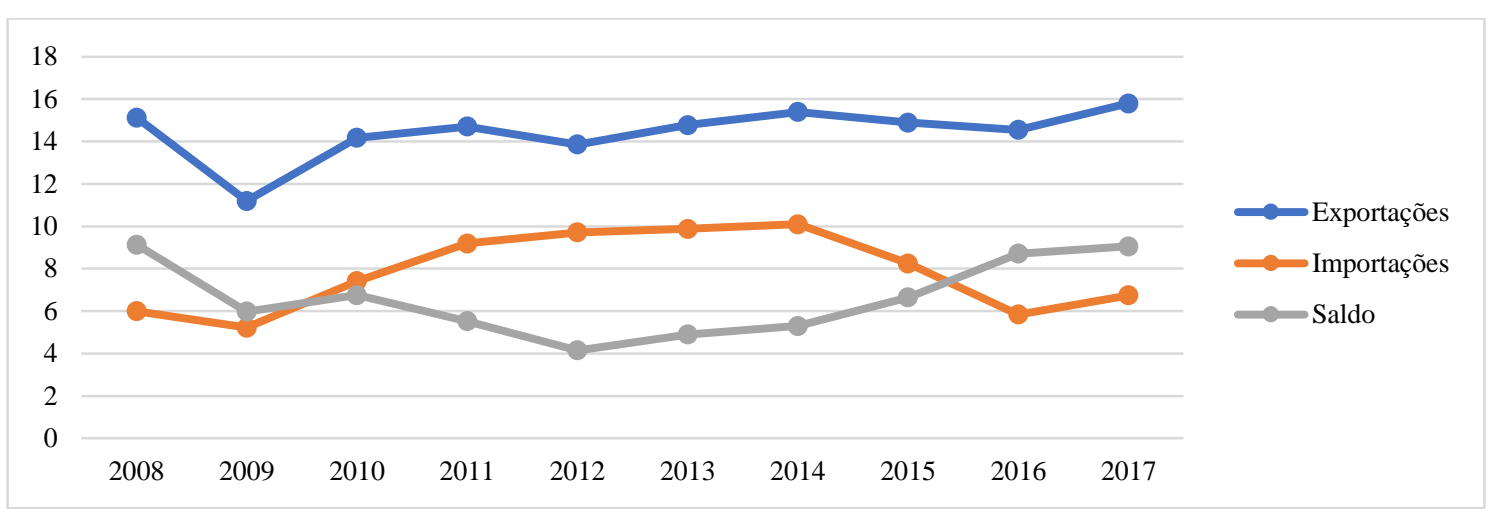

Fonte: MDIC. Elaboração própria

O superávit comercial diminuiu até 2012, o que pode ser explicado pelo crescimento das importações. Porém, a trajetória do saldo se reverteu a partir de 2013 em virtude da queda nas importações, sobretudo após 2014, quando se instala grave crise econômica no Brasil. $\mathrm{O}$ setor que apresentou o desempenho anual médio com maior proeminência nas exportações foi o setor de celulose, papel e produtos de papel. Este setor obteve uma média anual em suas exportações de US\$ 6,9 bilhões. Já referente as importações, o setor que se sobressaiu foi o de produtos têxteis apresentando uma média anual de US\$ 2,9 bilhões. Analisando o saldo 
comercial, observa-se que o maior superávit se encontra justamente em celulose, papel e produtos de papel constatando-se uma média anual de US\$ 5,3 bilhões. Já o maior déficit fica a cargo do setor de produtos têxteis registrando um déficit anual médio de US\$ 2 bilhões.

De forma articulada é possível analisar que embora o aumento no coeficiente de insumos importados denote quebra de elos de cadeias produtivas, nota-se que setores de baixa intensidade tecnológica, em conjunto, retomaram dinâmica externa após 2012, apresentando saldo positivo mais elevado na balança comercial. Porém, a maior integração com o exterior, principalmente nas importações, não significa, necessariamente, acesso a insumos mais elaborados e com preços mais competitivos, como sugere a ortodoxia.

Já a o novo desenvolvimentismo, neste caso, auxilia melhor na explicação, pois desde 2015 a taxa de câmbio nominal se desvalorizou (Gráfico 3), chegando ao patamar próximo a essa vertente recomenda como ideal para proporcionar competitividade à indústria (Bresser-Pereira, 2016).

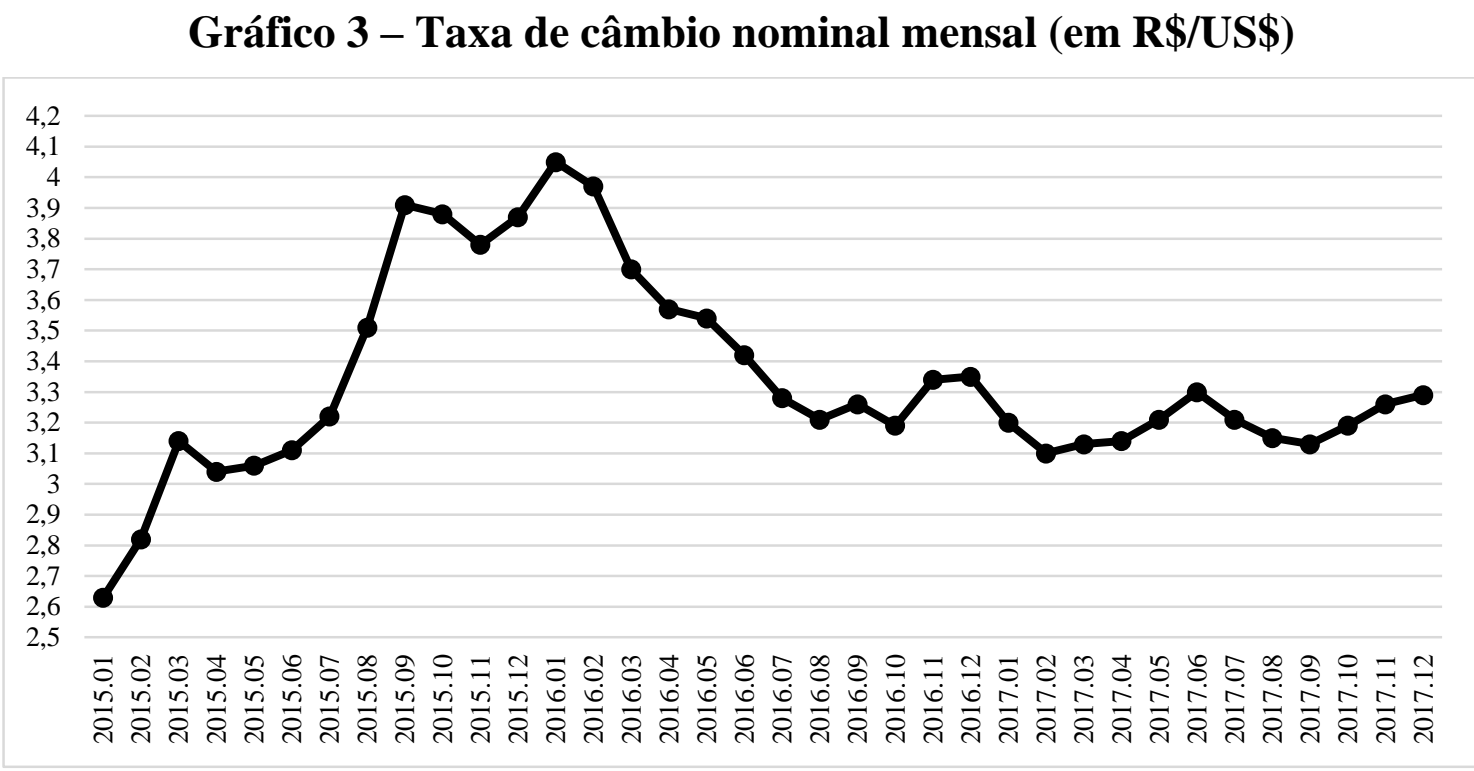

Fonte: IPEA. Elaboração própria.

A desvalorização cambial pode auxiliar os setores BIT porque ainda têm cadeias produtivas relativamente adensadas e relativamente mais simples e de mais fácil recomposição. Para fins de comparação, o setor têxtil brasileiro representa uma das últimas cadeias completas do Ocidente, atinge desde as fibras até as confecções (Almeida, 2014). Recorda-se que neste setor as exportações 
representam 3\% da produção, sendo as exportações insuficientes para acelerar a produção. Nesse sentido, a taxa de câmbio altera preços relativos e protege a produção nacional e suas cadeias produtivas.

$\mathrm{O}$ coeficiente de penetração de importações ${ }^{11}$ mostra a participação dos produtos importados no consumo aparente (a soma do valor da produção destinada ao mercado doméstico e das importações). Quanto maior o coeficiente de penetração, maior é a participação de importados no mercado interno (CNI, 2016). O coeficiente de penetração das importações do setor $\mathrm{k}$ é definido como:

$$
C P I_{k}=\frac{M_{k}}{\left(Y_{k}+M_{k}-X_{k}\right)}
$$

Onde:

$M_{k}$ é o valor de importações de produtos pelo setor k;

$Y_{k}$ é o valor da produção do setor $\mathrm{k}$;

$X_{k}$ é o valor das exportações do setor k; e

$\left(Y_{k}+M_{k}-X_{k}\right)$ é o valor do consumo aparente do setor $\mathrm{k}$.

O gráfico 4 descreve a evolução do coeficiente de penetração das importações para os setores de baixa intensidade tecnológica:

${ }^{11}$ O coeficiente de penetração de importações será utilizado como proxy para denotar a presença de desindustrialização relativa por substituição do produto final nacional pelo produto final importado. 


\section{Gráfico 4 - Coeficiente de penetração das importações da industria de transformação - Baixa intensidade tecnológica (preços constantes, em \%)}

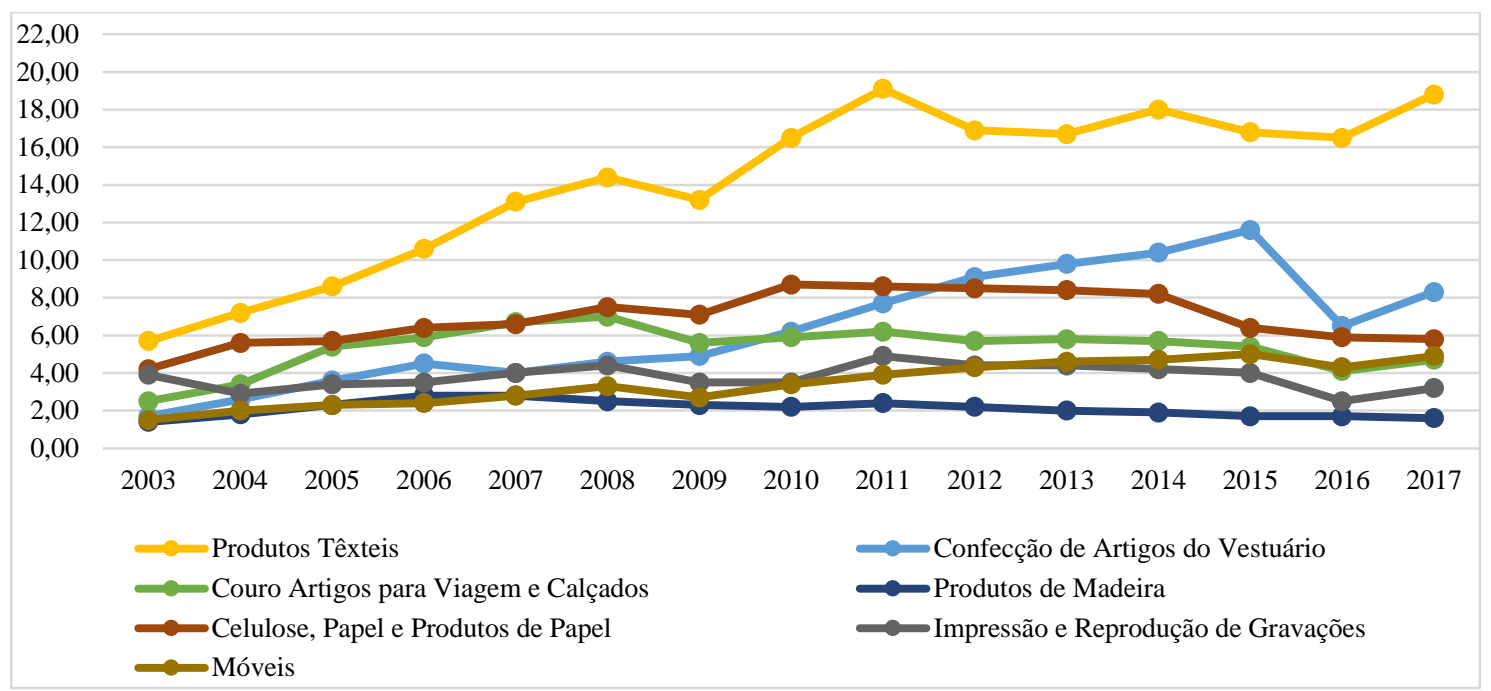

Fonte: CNI. Elaboração própria.

O maior destaque do gráfico 4, como visto anteriormente, é o setor têxtil, pois em 2003 apresentava coeficiente de 5,7\% e em 2017 18,8\%. No mesmo período, couro, artigos para viagem e calçados aumentou de $2,5 \%$ para $4,7 \%$; o de celulose, papel e produtos de papel de 4,2\% para 5,8\%; o de móveis de $1,5 \%$ para $4,9 \%$; confecção de artigos do vestuário e acessórios de 1,7\% para 8,3\%; produtos de madeira um ligeiro aumento de $1,4 \%$ para 1,6\%; e, por fim, impressão e reprodução de gravações, que foi o único setor a apresentar queda, de 3,9\% para 3,2\%.

Ao observar os coeficientes trazidos pelos gráficos 1 e 4 podemos encontrar uma possível explicação do porquê o setor têxtil apresentou o déficit anual médio mais relevantes dentre os setores analisados. O aumento da necessidade de importações de peças insumos e acessórios, assim como do produto final, criou uma pressão negativava na balança comercial deste setor. Os maiores déficits dentre os setores que foram analisados neste segmento tecnológico podem ser encarados como uma consequência da presença de sinais da desindustrialização relativa no setor de produtos têxteis. A desindustrialização, assim como seus efeitos nocivos no setor têxtil, também foi observada por Cano (2014):

O que também é muito grave, grandes empresas têxteis nacionais, como a Hering, que antes tinham na produção industrial sua principal atividade e, agora, regrediram para a atividade predominantemente comercial (Cano, 2014, p. 27). 
A combinação da elevação no coeficiente de penetração de importações em conjunto com o significativo aumento do coeficiente de insumos importados demonstrados explica, em parte, o aumento que as importações do setor de baixa tecnologia tiveram, principalmente entre 2009 e 2014. Segundo Morceiro (2018), essa dependência de importados nos setores de BIT não é maior porque o número de unidades industriais que obtém insumos via importação é relativamente baixo. Segundo ele, no biênio 2013-2014, 26,9\% das unidades industriais de produtos têxteis obtinham insumos via importação; couro, artigos para viagem e calçados 14,1\%; celulose, papel e produtos de papel 16,1\%; móveis $13,8 \%$; confecção de artigos do vestuário e acessórios 7,1\%; produtos de madeira 6,3\%; e, por fim, impressão e reprodução de gravações, $16,8 \%$.

O diretor comercial da CTM Fios, Carlos Madolo, apontou o caráter negativo da importação para o setor têxtil de produtos finais, como resultado do crescimento do coeficiente de penetração das importações:

[...] a desvalorização do real também traz um ponto positivo. $O$ varejo tende a importar menos, concentrando as compras na indústria nacional e a cadeia fica mais oxigenada (...) também seria importante mais equilíbrio nas importações. Deveria haver mais dificuldades para trazer o produto pronto [...] (Casarin, 2018, s.p.).

Portanto, analisando os dados apresentados até aqui, assim como as necessidades apontadas acima, uma estratégia que impulsione os setores de baixa intensidade tecnológica deveria focar na elaboração de um plano baseado em um conjunto de pontos que estão presentes nas três vertentes heterodoxas citadas na seção anterior:

i) a manutenção do câmbio em um patamar competitivo, como coloca a vertente do novo desenvolvimentismo: deve ser feita justamente, para o favorecimento das cadeias nacionais, oxigenando os elos ao longo dessas cadeias e impedindo que esses sejam fragilizados ou rompidos:

Para eliminar a desvantagem competitiva resultante da doença holandesa é preciso neutralizá-la, elevando (tornando mais depreciado) o equilíbrio corrente até ele se igualar ao equilíbrio industrial. Logrado esse objetivo, além da desvantagem competitiva desaparecer, há outra consequência importante: o país realizará um superávit em contacorrente (Bresser-Pereira, 2018, p. 50).

ii) o protecionismo moderado ou mesmo forte, como aponta a vertente estruturalista, impediria a importação do produto final (já que neste caso as 
unidades industrias nacionais se tornariam meras revendedoras e prestadoras de serviço), na medida em que o abandono desse tipo de política e a implementação de medidas liberais foram pontos fulcrais para criação de um ambiente marcado pela desindustrialização:

[...] a incapacidade da interpretação ortodoxa em explicar o declínio do dinamismo econômico brasileiro, mormente após os anos 1990, marcado pela supressão das restrições por ela apontada como cruciais, com destaque para o protecionismo característico da substituição de importações. Para avançar numa hipótese alternativa sobre o padrão de baixo dinamismo econômico, vigente no Brasil após os anos 1980, é necessário considerar, brevemente, os condicionantes interpostos ao desenvolvimento pelo novo contexto internacional, marcado pela globalização e também, pelos determinantes domésticos, seja a herança dos anos 1980, seja o novo perfil de política econômica de inspiração liberal, posto em prática nos anos 1990 (Carneiro, 2008, p. 12-13).

iii) o investimento em inovação e a tentativa, por parte de uma coalisão entre a iniciativa pública e privada, de modernizar os métodos de produção é uma das recomendações de maior importância para a vertente industrialista. Em outras palavras, diminuir o gap tecnológico ${ }^{12}$ entre as unidades industriais brasileiras e a dos demais países, segundo a vertente industrialista, é um ponto de grande importância. No entanto, isto não se apresenta como uma tarefa simples, justamente por envolver uma série de variáveis. Como sugere Diniz (2017):

[...] a definição de um plano nacional de desenvolvimento, compatibilizando e coordenando as dimensões macro (especialmente câmbio, juros e tributos) e setorial, e as diferentes instituições e órgãos de governo: a) Adequação e estabilização das políticas cambial e de comercio exterior; b) Ajuste da política monetária; c) Envolvimento do sistema empresarial; d) Estímulo e condicionante ao capital estrangeiro para internalizar o esforço de P\&D; e) Arrojado programa de ciência, tecnologia e inovação; f) Avanço da educação básica e profissionalizante; g) Expansão e modernização da infraestrutura; h) Reforma do sistema tributário; i) Redução dos entraves burocráticos e melhoria da gestão (Diniz, 2017, p. 24).

Embora a indústria brasileira ainda se apresente com um considerável grau de competitividade neste segmento tecnológico, a ausência de uma tomada de decisão que atenda os três pontos citados acima pode mudar a situação em um

\footnotetext{
$12 \mathrm{O}$ aumento do gap tecnológico é um dos principais fatores apontados pela vertente industrialista como fonte de desindustrialização no Brasil.
} 
futuro não muito distante, tanto para uma estratégia que vise beneficiar o mercado interno ou externo.

\subsection{Média-baixa intensidade tecnológica (MBIT)}

Nesta subseção serão investigados os sinais de desindustrialização relativa, seja por quebra de elos em cadeias produtivas, seja por substituição do produto nacional final pelo importado nos setores de média-baixa intensidade tecnológica (MBIT). No gráfico 5 está a evolução do CIP:

\section{Gráfico 5 - Coeficiente de insumos importados da indústria de transformação - Média-baixa intensidade tecnológica (preços constantes, em \%)}

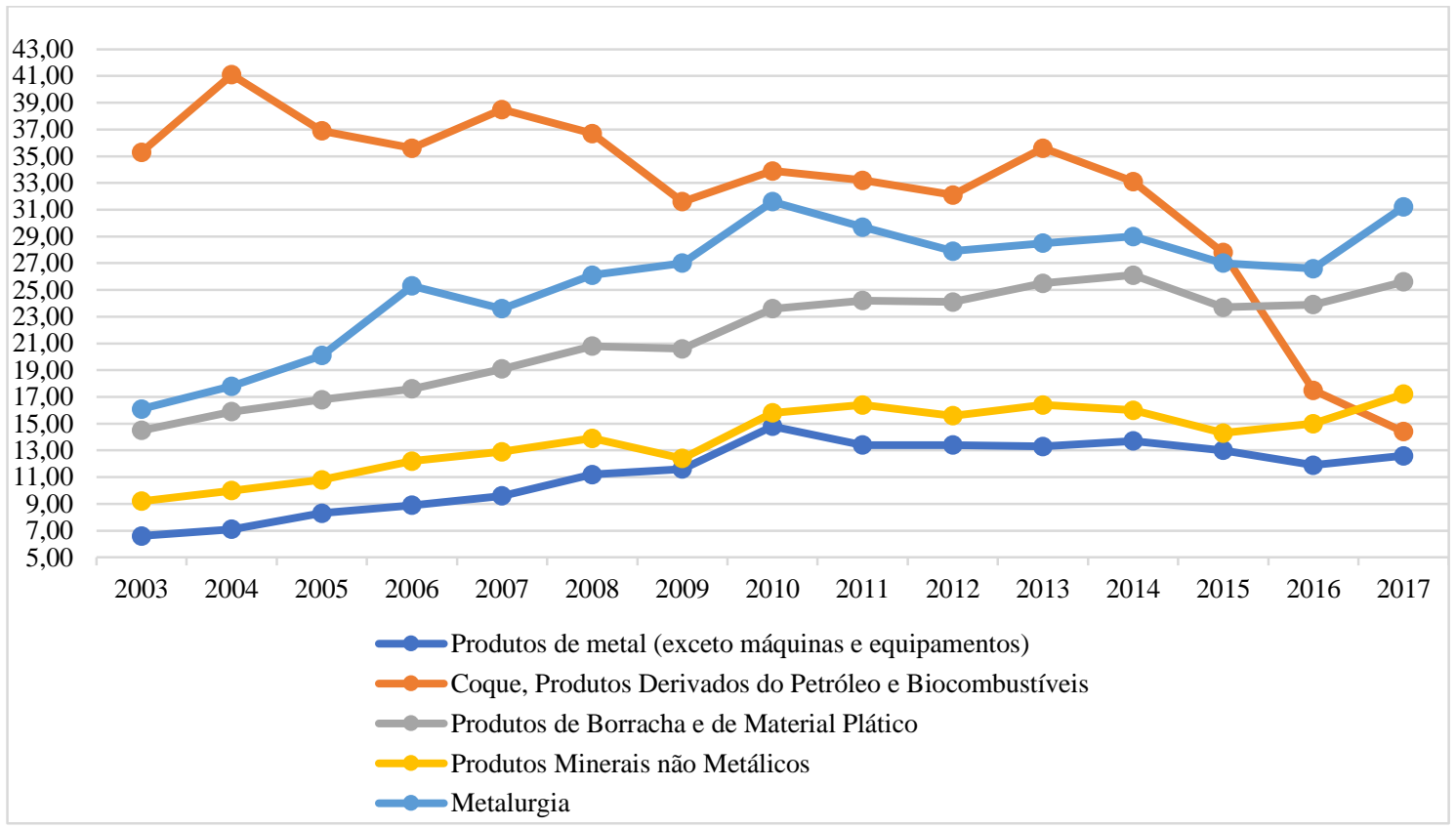

Fonte: CNI (vários anos). Elaboração própria

Todos os setores, exceto coque, produtos derivados do petróleo e biocombustíveis, apresentaram alta no coeficiente. Em 2003, o setor de produtos de metal (exceto máquinas e equipamentos) obtinha 6,6\% e, em 2017 foi 12,6\%. No mesmo período, produtos de borracha e de material plástico saltaram de 14,5\% para 25,6\%; produtos minerais não metálicos de $9,20 \%$ para 17,2\%; e produtos da metalurgia passou de $16,1 \%$ para $31,20 \%$. Assim, a dependência de insumos importados para a realização da produção aumentou substantivamente no período em questão. Coque, produtos derivados do petróleo e biocombustíveis apresentou índice de 35,3\% em 2003 e 14,4\% em 2017, sendo o único que apresentou queda. 
Este resultado pode ser explicado pela política de conteúdo nacional promovida pela Agência Nacional de Petróleo (ANP). Ainda assim, de forma geral, setores de MBIT sofreram desadensamento em cadeias produtivas.

O número de unidades industriais que obtiveram insumos via importação entre 2013-2014 é baixo: coque, produtos derivados do petróleo e biocombustíveis $12,3 \%$; produtos de borracha e de material plástico $23,8 \%$; produtos de minerais não metálicos $8,8 \%$; metalurgia $22,2 \%$; e produtos de metal (exceto máquinas e equipamentos) 12,9\% (Morceiro, 2018).

Na tabela 2 está descrita a evolução da produção física dos setores de médiabaixa intensidade tecnológica no período de 2008-2017:

Tabela 2 - Variação percentual da produção física industrial Média-baixa intensidade tecnológica

\begin{tabular}{c|c|c|c|c|c}
\hline Anos & $\begin{array}{c}\text { Coque, de } \\
\text { produtos } \\
\text { derivados do } \\
\text { petróleo e de } \\
\text { biocombustíveis }\end{array}$ & $\begin{array}{c}\text { Produtos de } \\
\text { borracha e } \\
\text { de material } \\
\text { plástico }\end{array}$ & $\begin{array}{c}\text { Produtos de } \\
\text { minerais } \\
\text { não-metálicos }\end{array}$ & Metalurgia & $\begin{array}{c}\text { Metal, exceto } \\
\text { máquinas e } \\
\text { equipamentos }\end{array}$ \\
\hline 2008 & 0,4 & 2,2 & 8,3 & 3,3 & 2,5 \\
\hline 2009 & $-0,8$ & $-9,3$ & $-4,6$ & $-17,6$ & $-14,7$ \\
\hline 2010 & 0,8 & 12,6 & 9,3 & 17,7 & 23,2 \\
\hline 2011 & 0,5 & $-1,2$ & 3,1 & $-0,4$ & 2,5 \\
\hline 2012 & 4,9 & $-1,5$ & $-0,7$ & $-4,1$ & $-2,4$ \\
\hline 2013 & 6,5 & 0,7 & 2,2 & 0 & $-1,6$ \\
\hline 2014 & 2,3 & $-3,6$ & $-2,5$ & $-7,4$ & $-10,1$ \\
\hline 2015 & $-5,9$ & $-9,3$ & $-7,7$ & $-8,4$ & $-11,5$ \\
\hline 2016 & $-8,5$ & $-6,6$ & $-10,6$ & -6 & $-10,6$ \\
\hline 2017 & $-4,2$ & 4,6 & $-2,2$ & 4,7 & $-1,4$ \\
\hline Taxa & $-0,50$ & $-1,34$ & $-0,73$ & $-2,22$ & $-2,92$ \\
\hline Média & $-0,5$ & & & \\
\hline
\end{tabular}

Fonte: IBGE (PIM-PF) Elaboração própria.

O setor que apresentou melhor resultado foi coque, produtos de derivados do petróleo e de biocombustíveis, porém com taxa média de variação de $-0,5 \%$. Todos os outros setores obtiveram desempenho pior: produtos de borracha e de material plástico, mineiras não-metálicos e metalurgia apresentaram resultados negativos em 6 anos e obtiveram, respectivamente, taxas médias de variação de $-1,34 \%,-0,73 \%$ e 
$-2,22 \%$. Por fim, o setor de metal, exceto máquinas e equipamentos obteve resultados negativos em 7 anos e uma taxa de variação média de $-2,92 \%$.

Comparando resultados do gráfico 5 com os da tabela 2 é notório que o setor de coque, produtos derivados do petróleo possivelmente passou por um processo de adensamento em cadeias produtivas, sendo o que apresentou os melhores resultados da produção física ${ }^{13}$. Por outro lado, metalurgia elevou seus insumos importados (15 p.p.) e teve o segundo pior resultado médio da produção física ($2,22 \%$ ), contrariando, mais uma vez, a tese ortodoxa. O gráfico 6 apresenta dados da dinâmica externa em MBIT:

\section{Gráfico 6 - Exportações, importações e saldo da balança comercial - Média-baixa intensidade tecnológica (US\$ milhões)}

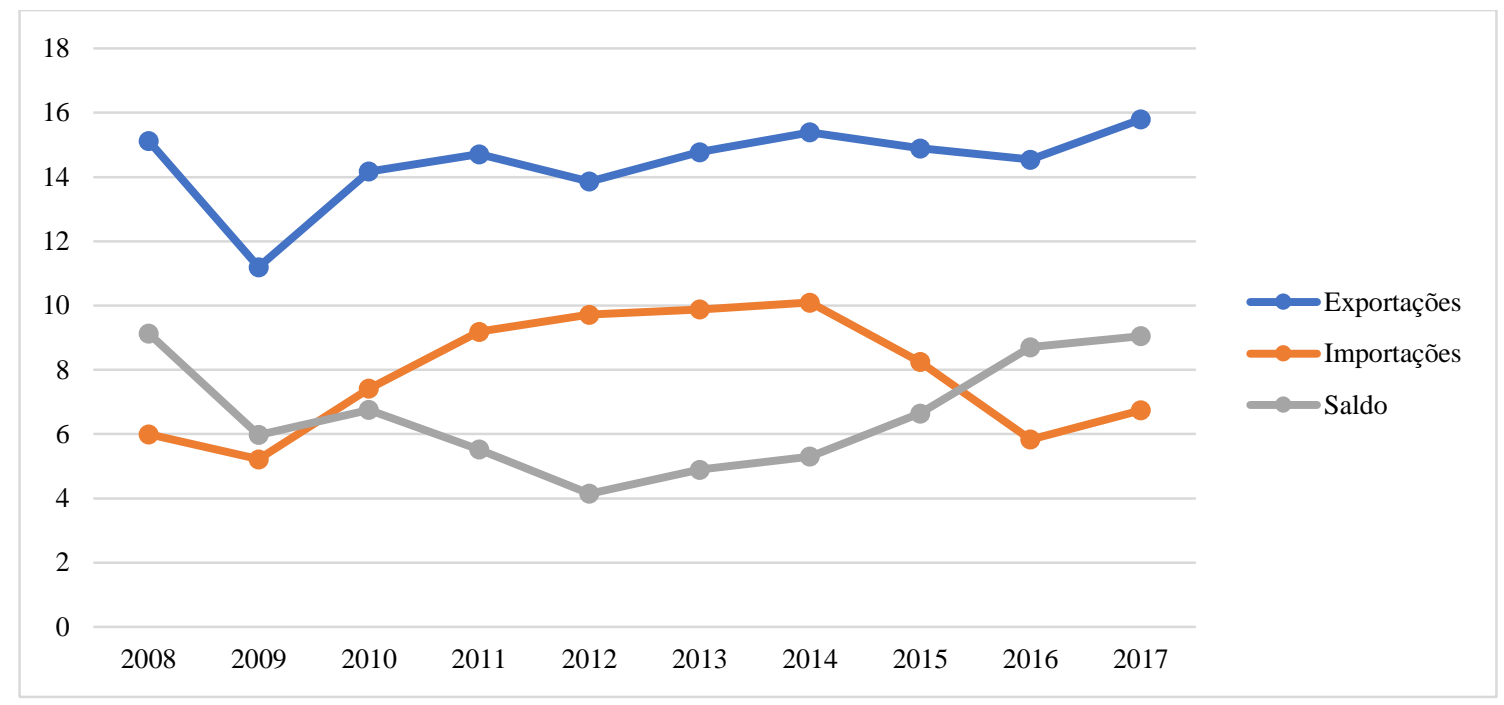

Fonte: MDIC. Elaboração própria.

Nota-se crescimento de exportações e importações até 2014, sempre com superávit comercial. Após este ano as exportações aumentam levemente e as importações caem. Estes movimentos ajudam a entender a evolução do saldo da balança comercial. O saldo comercial teve piora até 2012, após, teve crescimento, sobretudo em virtude da diminuição das importações.

Dentre os setores que foram levados em conta, o de metalurgia se sobressaiu nas exportações registrando uma média anual de US\$ 15,4 bilhões. Já nas importações, o setor de coque, produtos derivados de petróleo e biocombustíveis

\footnotetext{
${ }^{13}$ Ressalta-se este aspecto neste setor, porém não se vislumbra estabelecer correlação.
} 
registrou o valor médio anual mais significativo de US\$ 14,5 bilhões. Muito em função do bom desempenho nas exportações, o setor de metalurgia registrou os maiores superávits dentre os setores, registrando média anual de US\$ 7,4 bilhões. Já o setor que apresentou os maiores déficits foi justamente o de coque, produtos derivados de petróleo e biocombustíveis com déficit anual médio de US\$ 9,6 bilhões.

O aumento no coeficiente de insumos importados derivou de aumento consistente das importações, que levou a piora saldos comerciais com resultados negativos, principalmente após a crise de 2008. No gráfico 7 está a evolução do coeficiente de penetração das importações nesta tipologia:

\section{Gráfico 7 - Coeficiente de penetração das importações da indústria de} transformação - Média-baixa intensidade tecnológica (preços constantes, em \%)

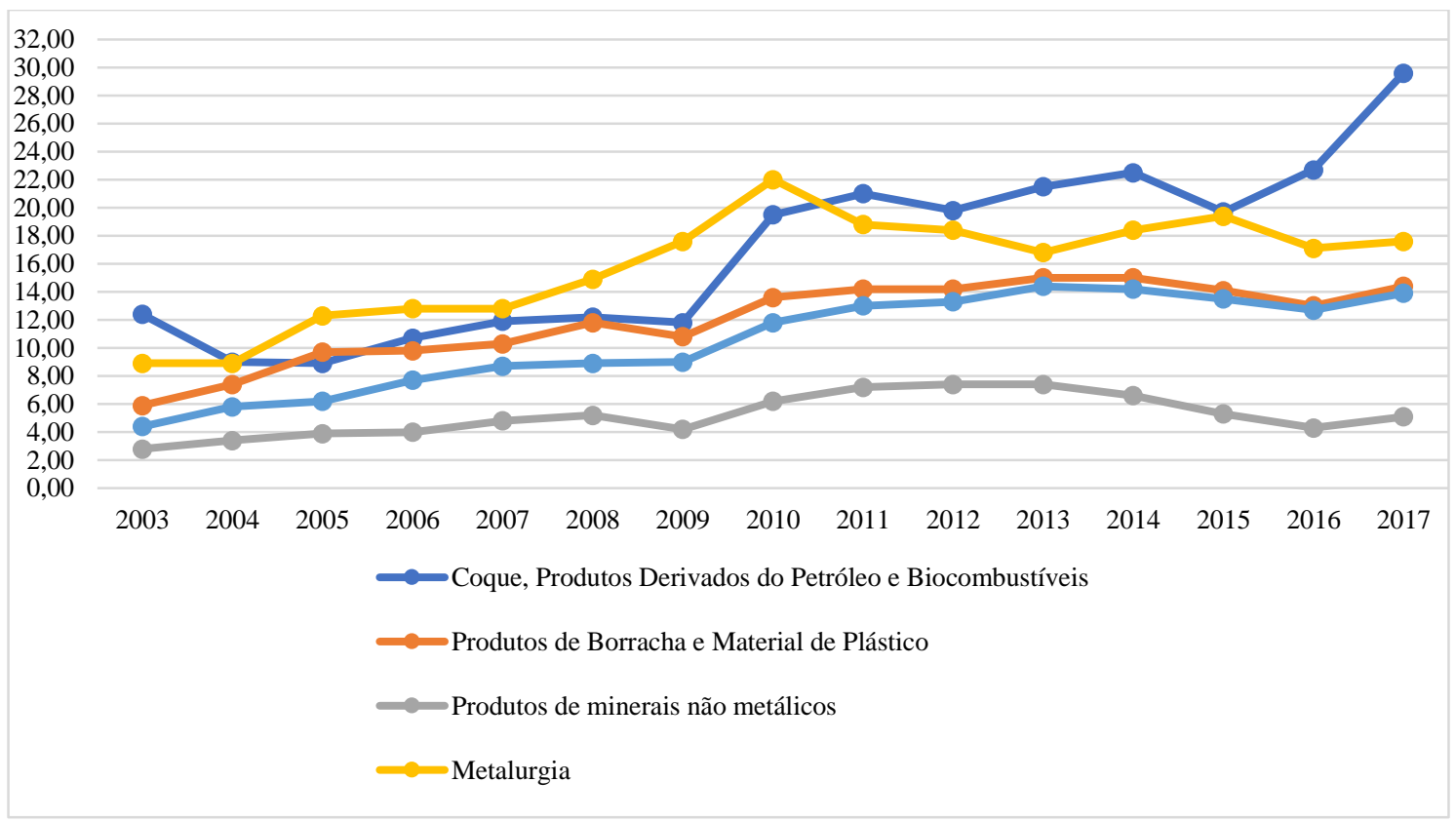

Fonte: CNI. Elaboração própria.

Todos os setores desta tipologia apresentaram alta no coeficiente de penetração das importações no período. Produtos de borracha e de material plástico tinha coeficiente de 5,9\% em 2003 e 14,4\% em 2017; produtos minerais não metálicos, no mesmo período, elevou o seu índice de 2,8\% para 5,1\%; metalurgia de $8,9 \%$ para $17,6 \%$; e produtos de metal (exceto máquinas e equipamentos) de $4,4 \%$ para $13,9 \%$.

Coque, produtos derivados do petróleo e biocombustíveis destoou porque o coeficiente de penetração das importações teve elevação de 12,9\% em 2003 para 
29,6\% em 2017, o que indica maior importação de produtos finalizados. Este movimento de ascensão do coeficiente de penetração de importações, neste período, pode ser um dos motivos pelo qual este setor apresentou o maior déficit anual médio dentre os setores analisados. Isto é, pode-se denotar que a presença de sinais de desindustrialização relativa por substituição do produto final nacional pelo importado, causou impactos no saldo comercial deste setor, haja vista que importar o produto diretamente pronto requer um dispêndio maior de divisas.

A partir disso, temos neste setor uma evidência de que os dois tipos de desindustrialização relativa tratados neste artigo não são simultâneos ou excludentes nos setores e por intensidade tecnológica.

Nota-se que todos os setores de média-baixa intensidade tecnológica apresentam aumento de importação de produtos finais, além de contribuírem negativamente para o resultado do saldo comercial. Desse modo, existem indícios de que os setores que compõem o segmento de média-baixa intensidade tecnológica apresentam sinais de desindustrialização relativa tanto por quebra de elos ao longo de cadeias produtivas, quanto pela substituição do produto final nacional pelo importado. A exceção encontrada é o setor de coque, produtos derivados do petróleo e biocombustíveis que, embora não tenha sinalização de quebra de elos, possui substituição do produto final pelo importado. Pode-se explicar o ocorrido, como fruto de uma estratégia nacional protecionista de aumento do conteúdo nacional, haja vista que gera renda e emprego, mantendo dos elos produtivos ou refazendo elos que foram rompidos, conforme defendido pela vertente estruturalista (Carneiro, 2008; Cano, 2014; Ricupero, 2010). Como já mencionado, a abertura comercial acentuada a partir dos anos 1990 e o abandono de estratégias de cunho protecionista é uma das principais fontes de desindustrialização:

[...] abertura desregrada pela qual o Brasil passou e passa desde 1989, ainda no governo Sarney, quando ocorre uma primeira investida quanto à proteção que tínhamos sobre as importações. Tal investida ampliouse sobremodo no governo Collor, em 1990. A terceira foi feita no governo de Fernando Henrique Cardoso, a partir de 1994, ampliada por nosso ingresso na OMC. Essa desregulamentação manteve-se e assim está até hoje. A abertura comercial com a queda das tarifas e demais mecanismos protecionistas da indústria nacional complementou o nocivo efeito do câmbio valorizado, reduzindo drasticamente o grau de proteção perante a concorrência internacional (Cano, 2014, p. 17-18). 
Membros e adeptos da vertente ortodoxa podem tecer críticas a este tipo de recomendação, justamente por enfatizar que medidas de cunho protecionista impedem que a unidades industriais brasileiras possam ter acesso a técnicas, peças, insumos e acessórios de qualidade. No entanto, o que se observa, de maneira geral, é que um aumento no coeficiente de insumos importados não se traduziu necessariamente em um aumento da competitividade. Portanto, a premissa ortodoxa de que níveis maiores de abertura se traduzem em maior competitividade, não se sustentam. Ademais, como trazem os dados, a abertura comercial desregrada se mostrou ser um dos agravantes da desindustrialização relativa em seus dois formatos (Carneiro, 2008; Cano, 2014; Sampaio, 2015; Colombo, 2019). Não obstante, esta análise vai também na contramão da vertente do novo desenvolvimentismo, já que ela, assim como a ortodoxa, é avessa a práticas protecionistas contemplando a promoção de exportações, tal qual explicado na seção anterior (Oreiro, 2016; Bresser-Pereira, 2018).

\section{Grupo 2: Média-alta e Alta intensidade tecnológica}

O objetivo será avaliar se existem indícios da presença de quebra de elos em cadeias produtivas e substituição do produto nacional final pelo importado para o grupo de maior intensidade tecnológica (média-alta e alta intensidade tecnológica). Dentro da dinâmica deste segmento podem surgir várias inovações que podem gerar uma série de externalidades positivas:

Quanto maior a exportação de produtos de empresas com maior intensidade tecnológica, maior sua aptidão tecnológica para colocar produtos de elevado valor agregado no mercado internacional. Ademais, as exportações podem permitir um processo de aprendizado (importante para o processo inovativo da empresa exportadora), se envolver a interação com fontes de conhecimentos externos, tais como clientes, fornecedores de bens de capital etc. (Chiarini; Silva, 2016, p. 1008).

Segundo Ricúpero (2010), a taxa de câmbio teve papel relevante para o agravamento da desindustrialização nos setores do Grupo 2:

O câmbio já está estrangulando o setor de maior tecnologia e valor agregado de nossa indústria [...] ...e a desindustrialização precoce entra no segundo estágio de agravamento. No primeiro, as importações substituem os componentes locais, mas o produto continua a ser montado no Brasil; no segundo, importa-se o produto pronto e as indústrias se tornam meras distribuidoras e prestadoras de assistência (Ricupero, 2010, s.p.). 
Assim, ressalta-se a sua importância para a compreensão da desindustrialização, da dinâmica da concorrência e do papel do Brasil na divisão internacional do trabalho.

\subsection{Média-alta intensidade tecnológica (MAIT)}

No gráfico 8 encontra-se a evolução do coeficiente de insumos importados dos segmentos de média-alta intensidade tecnológica entre 2003-2017:

\section{Gráfico 8 - Coeficiente de insumos importados da indústria de transformação - Média-alta intensidade tecnológica (preços constantes, em \%)}

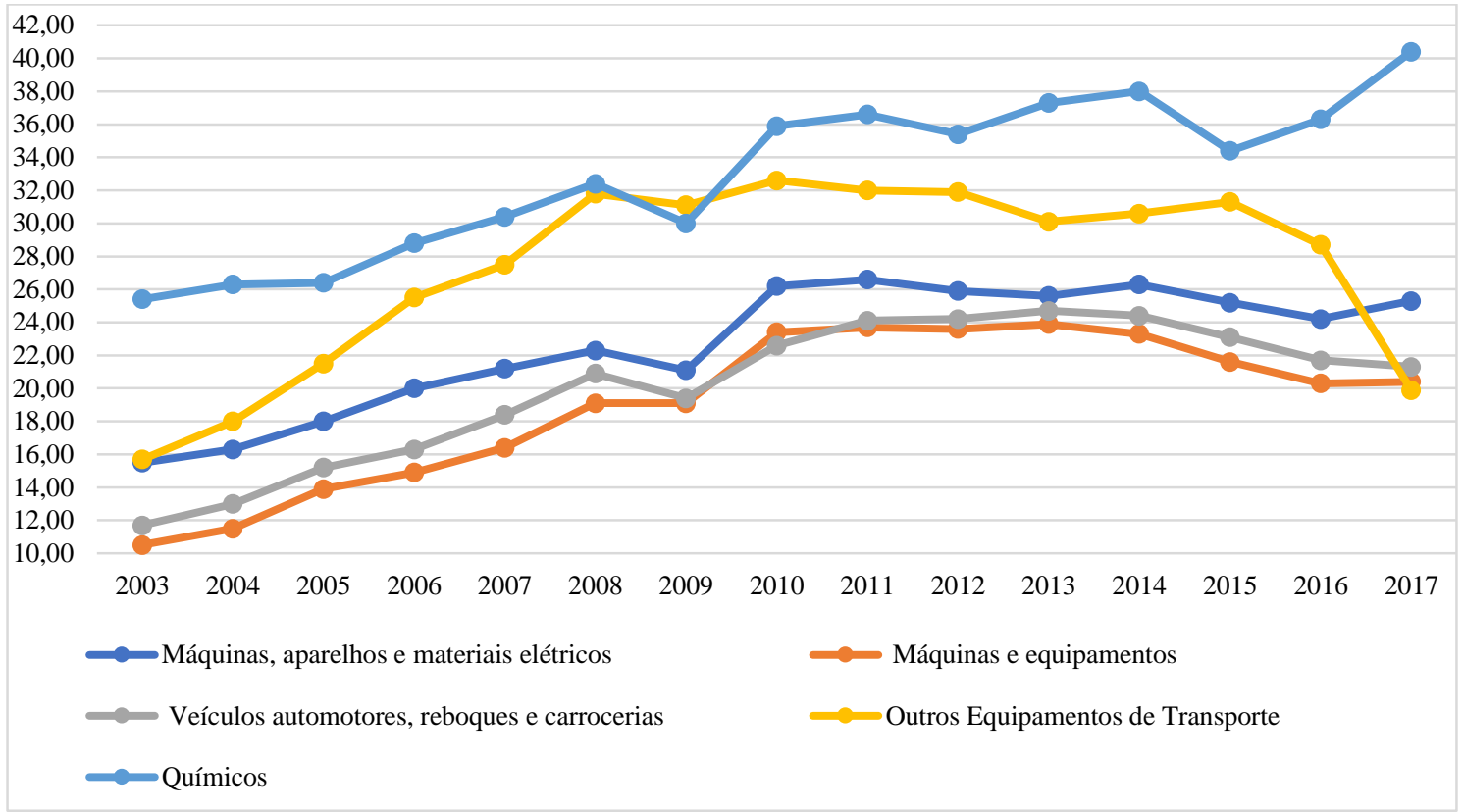

Fonte: CNI. Elaboração própria.

Todos os setores apresentam aumento no coeficiente de importação de insumos. Porém, os valores encontram-se em patamar maior do que os do Grupo 1. Máquinas, aparelhos e materiais elétricos obtinha coeficiente de 15,5\% em 2003 e $25,3 \%$ em 2017; máquinas e equipamentos passou de $10,5 \%$ para $20,4 \%$; veículos automotores, reboques e carrocerias, de 11,7\% para 21,3\%; outros equipamentos de transporte, de $15,7 \%$ para $19,9 \%$ (nota-se o pico de $32,6 \%$ em 2010); e, por fim, químicos passou $25,4 \%$ para $40,4 \%$.

Ferraz, Gutierre e Cabral (2015), através da matriz insumo-produto, analisaram a evolução da indústria manufatureira entre 1995 e 2011 . No estudo, eles constataram aumento da importação de bens intermediários, sendo os 
resultados mais intensivo nos setores mais sofisticados. Ainda, nota-se a China como principal fornecedora desses insumos, enfatizando novas configurações na divisão internacional do trabalho:

De acordo com os resultados [...], o Brasil tem desenvolvido [...] desvantagens em setores mais sofisticados, o que vem se acentuando [...]. Em particular, setores mais sofisticados, tais como Equipamento de Transporte, Químico e Equipamentos Elétricos e Ópticos estão cada vez mais perdendo vantagem comparativa na produção de bens intermediários [...] Em síntese, as evidências apontam que na última década parece ter havido uma melhora da integração produtiva de todos os setores do Brasil, no que tange à participação de produtos intermediários importados. Esse aumento foi relativamente maior em setores de tecnologia mais avançada e a principal fonte desses bens foi a China, a qual ganhou espaço em detrimento da produção doméstica brasileira (Ferraz; Gutierre; Cabral, 2015, p. 221).

Para eles, o resultado representa uma maior integração do Brasil nas “cadeias globais de valor" (CGV). Assim, a desindustrialização não aparece como problema a ser enfrentado, pois interessa a integração às CGV's, porém não se realiza uma crítica à forma de integração. $\mathrm{O}$ número de unidades industriais que obtiveram insumos via importação no biênio 2013/2014 neste segmento é mais elevado que o analisado anteriormente: no setor de químicos 46,2\%; máquinas, aparelhos e materiais elétricos $40 \%$; máquinas e equipamentos $38,8 \%$; veículos automotores, reboques e carrocerias 39,5\%; outros equipamentos de transporte 43,3\% (Morceiro, 2018). Na tabela 3 apresenta-se a taxa de variação da produção física no período entre 2008-2017. 
Tabela 3 - Variação percentual da produção física industrial Média-alta intensidade tecnológica (em \%)

\begin{tabular}{c|c|c|c|c|c}
\hline Anos & Químicos & $\begin{array}{c}\text { Máquinas, } \\
\text { aparelhos e } \\
\text { materiais } \\
\text { elétricos }\end{array}$ & $\begin{array}{c}\text { Máquinas equipamentos } \\
\text { equículos }\end{array}$ & $\begin{array}{c}\text { Veícomotores, } \\
\text { automos } \\
\text { reboques e } \\
\text { carrocerias }\end{array}$ & $\begin{array}{c}\text { Outros } \\
\text { equipamentos } \\
\text { de transporte }\end{array}$ \\
\hline 2008 & $-1,4$ & 2,7 & 8,1 & 7,7 & 42,2 \\
\hline 2009 & $-4,3$ & $-9,7$ & $-27,4$ & $-12,1$ & 2,3 \\
\hline 2010 & 10,2 & 7,5 & 32,8 & 23,6 & $-0,1$ \\
\hline 2011 & $-2,1$ & $-1,4$ & $-0,2$ & 2,3 & 7,9 \\
\hline 2012 & 3,4 & $-0,7$ & $-5,3$ & $-13,5$ & 8,6 \\
\hline 2013 & 4,7 & 3,2 & 4,1 & 9,6 & 1,9 \\
\hline 2014 & $-3,9$ & -7 & $-5,7$ & $-16,8$ & $-0,3$ \\
\hline 2015 & $-6,2$ & -12 & $-14,5$ & $-25,9$ & $-9,3$ \\
\hline 2016 & -1 & $-7,3$ & $-11,7$ & $-12,1$ & $-19,7$ \\
\hline 2017 & 0,6 & $-3,5$ & 2,8 & 17,2 & $-10,3$ \\
\hline Taxa & $-0,11$ & $-3,00$ & $-2,83$ & $-3,22$ & 1,23 \\
Média & -12 & & & \\
\hline
\end{tabular}

Fonte: IBGE (PIM-PF). Elaboração própria.

Mais uma vez, em geral, os resultados são negativos, tendo, como exceção o setor de outros equipamentos de transportes, que pode ser explicado pela política pública de incentivo à compra e financiamento de caminhões, bem como a produção e exportação de aviões puxada pela Embraer. Químicos e máquinas e equipamentos apresentaram resultados negativos em 6 anos; máquinas, aparelhos e materiais elétricos em 7 anos; e, por fim, o de veículos automotores, reboques e carrocerias e o de outros equipamentos de transporte, em 5 anos. O resultado de outros equipamentos de transportes foi excepcional em 2008 (42,2\%), em 2011 $(7,9 \%)$ e em $2012(8,6 \%)$, o que o configura como um outlier nesta tipologia. Novamente, o aumento no coeficiente de insumos importados não se traduziu em um aumento de produção física. Para complementar, dados da dinâmica externa são apresentados no gráfico 9: 


\section{Gráfico 9 - Exportações, importações e saldo da balança comercial - Média-alta intensidade tecnológica (US\$ milhões)}

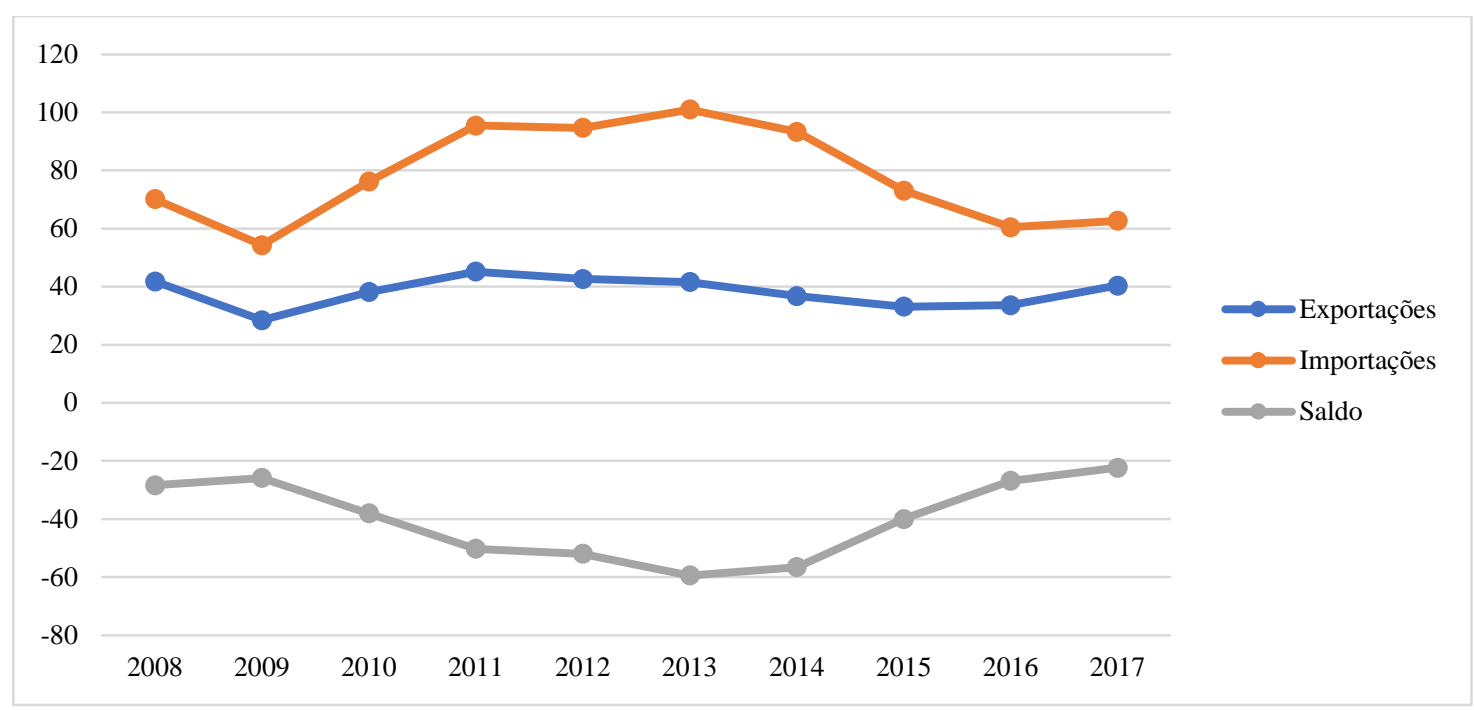

Fonte: MDIC. Elaboração própria.

Após 2008 as exportações e importações recuperaram, porém em intensidades distintas. Entre 2009 e 2011, as exportações aumentaram em US\$ 16,72 bilhões e as importações aumentaram em US\$ 41,17 bilhões. E, posteriormente, houve queda nas exportações, porém as importações demoram um período de pelo menos dois anos para também entrar em queda, marcando novamente uma "rigidez".

Dos setores descritos no gráfico 9, o que apresentou o maior valor médio anual nas exportações foi o de veículos automotores, reboques e carrocerias, por volta de US\$13,9 bilhões. Já em relação às importações, o setor de produtos químicos registrou o proeminente valor médio anual de US\$ 38,8 bilhões. Muito em função disto, o setor de produtos químicos também registrou o maior déficit médio anual, cerca de US\$ 19 bilhões. Nenhum dos setores analisados registrou saldo superavitário.

Mais uma vez, os sinais da presença de desindustrialização relativa aparentam trazer consequências ao saldo da balança comercial, em especial do setor com maior déficit, o de produtos químicos. Através do gráfico 8 podemos ver o aumento substancial da necessidade da importação de peças insumos e acessórios deste setor. Provavelmente essa evasão de divisas repercutiu negativamente no saldo da balança comercial, a tornando fortemente negativa como citado anteriormente. 
A partir dos dados e indicadores, duas questões são levantadas: (i) a "rigidez" que as importações impactaram no saldo comercial e (ii) a magnitude do déficit do saldo comercial é preocupante, porque cria pressões no balanço de pagamentos. Esses bens de maior intensidade tecnológica apresentam maior elasticidade-renda da demanda tanto de exportação quanto de importação.

Segundo Araújo e Marconi (2015), uma possível saída é adotar medidas que incentivem exportações e reduzam importações, a fim de relaxar a restrição externa nesta tipologia. Cassiolato (2015) e Cassiolato e Lastres (2001), nesse sentido, argumentam que a partir da década de 1990 iniciou-se, no Brasil, uma desnacionalização que afetou, principalmente, setores de maior intensidade tecnológica. Como proxy para mensurar a vulnerabilidade desses setores, eles se embasaram em dados semelhantes aos apresentados no gráfico 9. Cassiolato (2015), argumentam que o problema já se apresentava no início da década de 2000, porém foi suavizado devido ao forte ciclo de commodities. Após, as debilidades nacionais foram novamente ressaltadas, criando distintas pressões nas contas externas.

Da mesma forma que ocorre nos outros segmentos tecnológicos, o alto valor das importações não é causado apenas pelas importações de insumos. O coeficiente de penetração das importações demonstra como a importação de produtos finais contribui negativamente para o saldo comercial (Gráfico 10).

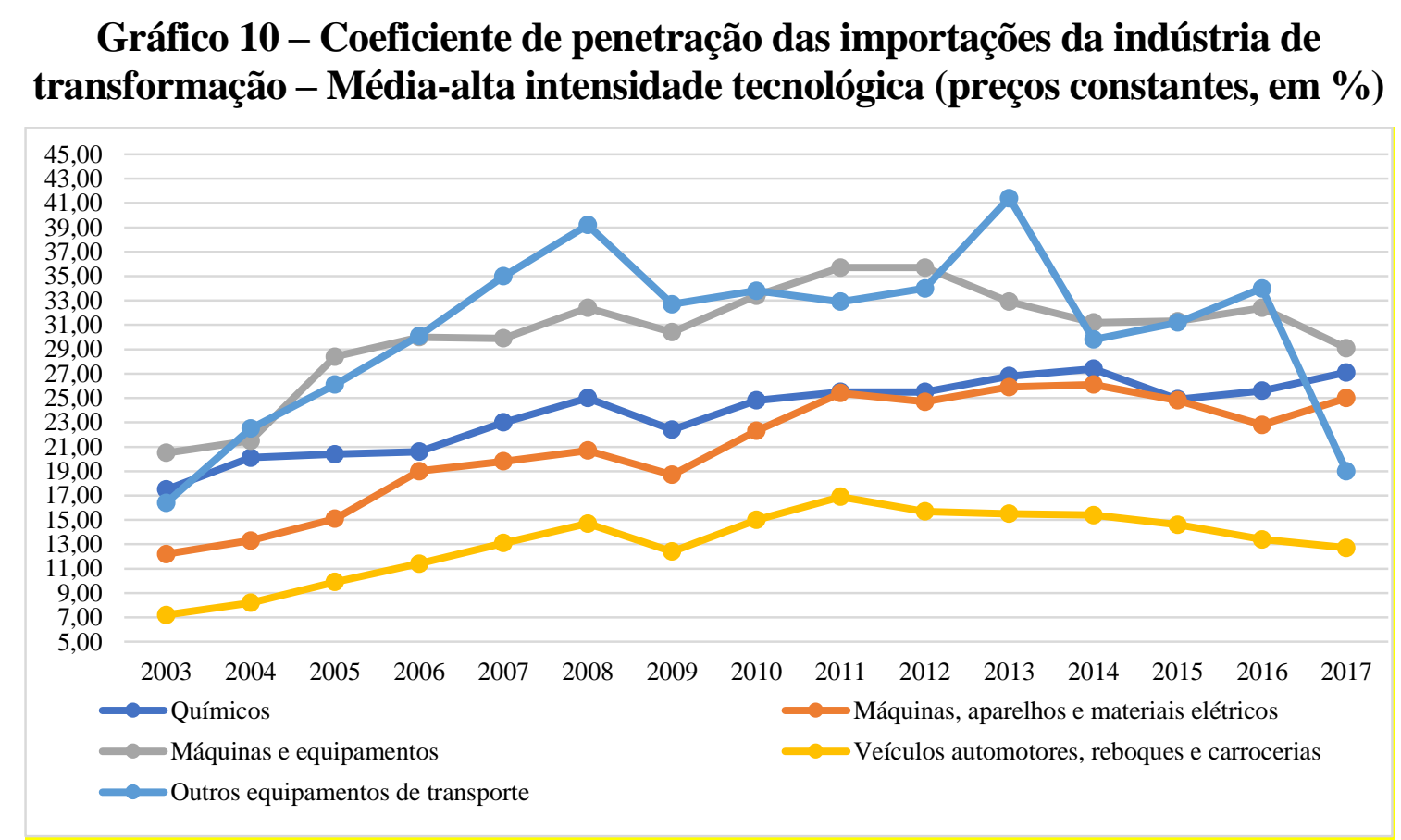

Fonte: CNI. Elaboração própria. 
Todos os setores também apresentam trajetória de alta. O setor de químicos tinha coeficiente de penetração das importações de 17,5\% em 2003 e 27,1\% em 2017. O setor de máquinas e equipamentos passou de $20,5 \%$ para $29,1 \%$; veículos automotores, reboques e carrocerias de $7,2 \%$ para $12,7 \%$; máquinas, aparelhos e materiais elétricos passou de $12,2 \%$ para $25,0 \%$. Já o setor de outros equipamentos de transporte teve comportamento errático, pois iniciou a série com 16,4\% em 2003, 41,4\% em 2013, com seguidas quedas, alcançando $19 \%$ em 2017. Assim, evidenciase nestes setores com maior intensidade tecnológica uma maior necessidade da importação de produtos finais. Além disso, recorda-se que o parque industrial brasileiro não incorporou vários setores e elos que foram gerados com a terceira revolução industrial (Morceiro, 2018; Morceiro; Guilhoto, 2019). Sarti e Hiratuka (2018) analisam o aumento dos coeficientes como um dos determinantes para os resultados negativos (como a taxa de variação física por exemplo):

O ponto a ser destacado é que a evolução pífia do produto industrial no período 2011-2014 não se deveu à insuficiência de demanda, mas sim a seu vazamento para o exterior. A insuficiência de demanda vai se configurar posteriormente. A partir de 2015, observou-se pela primeira vez desde 2003 a retração do consumo, que, somada à queda exponencial dos investimentos iniciada em meados de 2013, promoveu uma forte contração do produto industrial. Nem mesmo a redução das importações e a ligeira recuperação das exportações industriais em 2015 alteraram a trajetória de queda do produto industrial (Sarti; Hiratuka, 2018, p. 141)

Ainda no gráfico 10, os setores de MAIT parecem ser atingidos pela desindustrialização por substituição do produto final nacional pelo produto final importado, ou segundo estágio como afirmou Ricúpero (2010). Morceiro (2012) analisou este indicador com algumas alterações metodológicas e com um período de análise reduzido (2000-2008), chegando a resultado parecido. Ele afirmou que $\mathrm{o}$ indicador sugere um desmantelamento de algumas cadeias produtivas nacionais, principalmente as mais complexas. Chiarini e Silva (2016) avaliam a qualidade da inserção externa brasileira por intensidade tecnológica nas décadas de 1990 e 2000, principalmente após a abertura comercial. A conclusão foi que o Brasil passou a ser fortemente depende de importações de produtos pertencentes aos setores de maior intensidade tecnológica, sem conseguir modernizar sua estrutura produtiva:

Embora o país tenha aumentado seu grau de abertura, a inserção das exportações brasileiras de produtos industrializados com alto e médio-alto conteúdo tecnológicos é escassa e frágil, apoiando-se em uma marcante especialização de exportações de produtos de baixo e médio-baixo conteúdos tecnológicos [...] (Chiarini; Silva, 2016, p. 1036-1037). 
Esses estudos corroboram com a evolução do indicador de penetração das importações, demonstrando assim espécie de inaptidão tecnológica da indústria nacional. Assim, é possível perceber que setores da indústria de média-alta intensidade tecnológica apresentam sinais de desindustrialização por quebra de elos de cadeias produtiva e por substituição produto nacional final pelo importado. Todavia, neste último, em especial, os indicadores são mais expressivos.

Através das vertentes de pensamento listadas anteriormente, novamente podemos constatar alguns pontos importantes que explicam os motivos do porquê a desindustrialização traz consequências relativamente mais intensa nestes setores de maior intensidade tecnológica. A vertente do novo desenvolvimentismo aponta o câmbio como fundamental para a indústria de maneira geral, porém o que se nota é que os setores de maior intensidade tecnológica são ainda mais dependentes desta variável, de modo que se o câmbio ficar em um patamar que desestimule a produção, poderia ocorrer uma substituição quase que imediata da produção nacional pelo produto final importado:

Uma taxa de câmbio apreciada interrompe o acesso das empresas ao mercado doméstico porque mesmo as empresas mais eficientes não conseguem competir com os importadores que colocam seus produtos a um preço artificialmente mais barato - quando cotado na moeda nacional - no mercado interno, e os exportadores não conseguem uma receita em reais adequada que os estimule a vender no exterior, mantido o preço constante na moeda estrangeira (Marconi, 2020, s.p.).

Junto com isso podemos elucidar a importância de medidas protecionistas, como recomenda a vertente estruturalista uma vez que estes setores já se encontram maduros em países desenvolvidos. Assim, a indústria nacional necessita de proteção ou, caso contrário, a economia passará a ser inundada de importados, forçando a balança comercial deste segmento tecnológico a apresentar resultados fortemente negativos:

A verdadeira "avalanche" de importações, principalmente quanto aos bens de consumo duráveis, deu-se graças ao dólar barato e à abertura comercial mal negociada. Esse aumento de importações vem, em parte, quebrando ou debilitando elos de várias cadeias produtivas e, assim, eliminando empresas e linhas produtivas de várias empresas. Ao mesmo tempo, o fenômeno é altamente inibitório do investimento normal e daquele típico inovador ou mesmo o que complementa cadeias produtivas. Há de se entender que eliminar uma empresa é relativamente fácil, em tais circunstâncias. Destruir uma liderança industrial nacional, um empresário industrial dinâmico, como ocorreu com vários, também é fácil. $\mathrm{O}$ difícil é criar ou tentar recriar tais empresas e respectivas lideranças. Criar e recriar empresas nacionais 
expressivas e grandes como as do grupo de Mindlin [Metal Leve, do setor de autopeças] ou outras, como a Kasinski, que antes produziam peças e exportavam-nas aos mercados norte-americano e europeu para se transformarem em simples montadoras de motocicletas na Zona Franca de Manaus (Cano, 2014, p. 27).

Por fim, as recomendações da vertente industrialista são as de maior importância, porque com a perda da capacidade de promover o catching up, principalmente do ponto de vista tecnológico, o Brasil passou a ter um distanciamento das sofisticadas técnicas de produção, também chamadas de técnicas de pontas. Essas técnicas são de extrema importância para produtos de elevada intensidade tecnológica e, portanto, para uma política industrial que vise a inovação como objetivo central. Retomar a capacidade de catching up é de suma importância para a recuperação destes setores em específico, ou seja, em um estado de falling behind se torna praticamente impossível ser competitivo no cenário externo no mercado de produtos com elevado grau de sofisticação:

\begin{abstract}
A redução dos adensamentos produtivos e o maior grau de especialização regressiva da estrutura produtiva reduziram os encadeamentos produtivos e tecnológicos. A baixa taxa de investimento industrial afastou a indústria brasileira da fronteira tecnológica. Essa fragilidade produtiva e tecnológica é particularmente preocupante diante do novo desafio que se desenha globalmente a partir da trajetória de algumas tecnologias disruptivas, que tendem a mudar os patamares e os requisitos de competitividade dos setores industriais atuais (internet das coisas, internet móvel, nuvens, robótica avançada, veículos autônomos, genômica, armazenamento de energia, energias renováveis, impressão em 3D, entre outras). Assim como o processo de "chinalização industrial" impôs um novo patamar de economias de escala e de escopo, e, portanto, de competitividade, para uma gama ampla de setores industriais, esse cluster de inovações promoverá mudanças estruturais de competitividade. $\mathrm{O}$ desenvolvimento e a difusão dessas tecnologias no Brasil poderão ser dificultados pelo fato de que o país ainda nem sequer internalizou de forma adequada os setores da terceira revolução tecnológica (TICs, além de outras áreas tecnológicas importantes como biotecnologia, nanotecnologia etc. (Sarti; Hiratuka, 2018, p. 167-168).
\end{abstract}

Mais uma vez é possível denotar a dinâmica complexa que a desindustrialização apresenta no Brasil, na medida em que o processo possui sinais de ocorrência em mais de um formato. Não obstante, nenhuma das vertentes utilizadas para a análise dos dados, de maneira isolada, parece apresentar um escopo teórico que abarque todos as fontes e as recomendações para superar o processo, o que reitera seu caráter complexo, diverso e multiformato. 


\subsection{Setores de alta intensidade tecnológica}

$\mathrm{Na}$ busca de verificar sinais de desindustrialização relativa para este segmento, veja-se o gráfico 11:

Gráfico 11 - Coeficiente de Insumos Importados da Indústria de Transformação - Alta intensidade tecnológica (preços constantes, em \%)

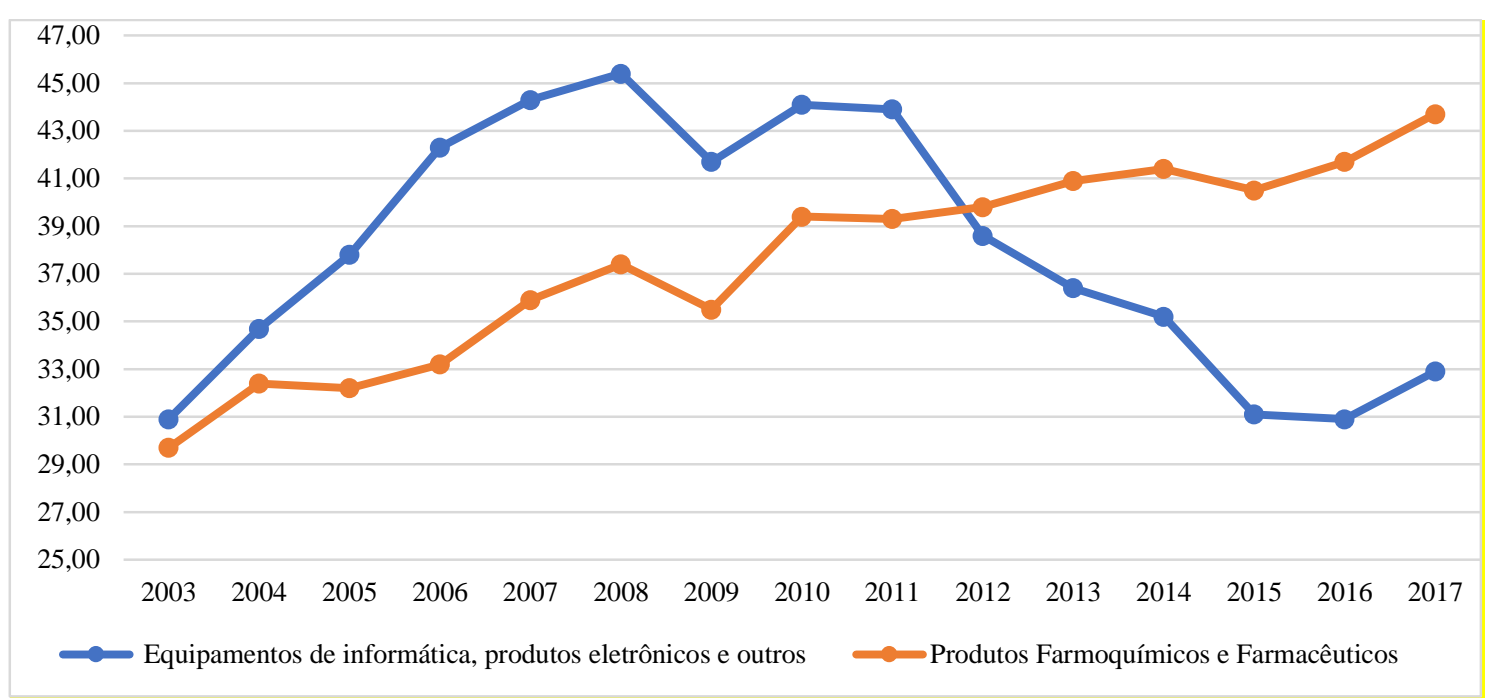

Fonte: CNI. Elaboração própria.

Em 2003, equipamentos de informática, produtos eletrônicos e outros importava 30,9\% dos insumos; já produtos farmoquímicos e farmacêuticos $29,7 \%$. Em 2017, respectivamente, os coeficientes são de 32,9\% e 43,7\%. Cabe destaque a equipamentos de informática, produtos eletrônicos e outros, que apresentou uma evolução errática. Entre 2003 e 2011 o indicador aumentou 13 p.p., porém a partir de 2012 teve queda, alcançando 32,9\% em 2017, valor próximo ao de 2003.

O número de empresas que obtém insumos via importação destes dois setores é substancialmente maior que as demais tipologias por intensidade tecnológica. Equipamentos de informática, produtos eletrônicos e outros obteve 63,3\%; produtos farmoquímicos e farmacêuticos 64,5\% (Morceiro, 2018), dados que reforçam a dependência da importação de insumos industriais.

$\mathrm{Na}$ tabela 4, a seguir, apresenta-se a variação percentual da produção física. 
Tabela 4 - Variação percentual da produção física industrial Alta intensidade tecnológica (em \%)

\begin{tabular}{c|c|c}
\hline Anos & $\begin{array}{c}\text { Produtos farmoquímicos e } \\
\text { farmacêuticos }\end{array}$ & $\begin{array}{c}\text { Equipamentos de informática, } \\
\text { produtos eletrônicos e outros }\end{array}$ \\
\hline 2008 & 12,7 & $-2,9$ \\
\hline 2009 & 8 & $-18,8$ \\
\hline 2010 & 2,3 & 8,3 \\
\hline 2011 & 3,1 & 1,5 \\
\hline 2012 & 0,2 & $-11,8$ \\
\hline 2013 & $-0,6$ & 4,6 \\
\hline 2014 & 2,5 & $-3,1$ \\
\hline 2015 & $-12,4$ & $-30,1$ \\
\hline 2016 & $-1,7$ & -14 \\
\hline 2017 & $-5,2$ & 20,2 \\
\hline Taxa Média & 0,68 & $-5,64$ \\
\hline
\end{tabular}

Fonte: IBGE (PIM-PF). Elaboração própria.

Equipamentos de informática, produtos eletrônicos e outros apresentou variação média da produção física em $-5,64 \%$. Nele, houve variação negativa em seis anos, com destaque para 2015 (-30,1\%). Produtos farmoquímicos e farmacêuticos teve taxa de variação média de $0,68 \%$, com resultados negativos em apenas quatro anos. Estes números indicam, no mínimo, uma estagnação em alta intensidade tecnológica. No gráfico 12, a seguir, apresentam-se resultados da dinâmica externa:

\section{Gráfico 12 - Exportações, importações e saldo da balança comercial - Alta intensidade tecnológica (US\$ milhões)}

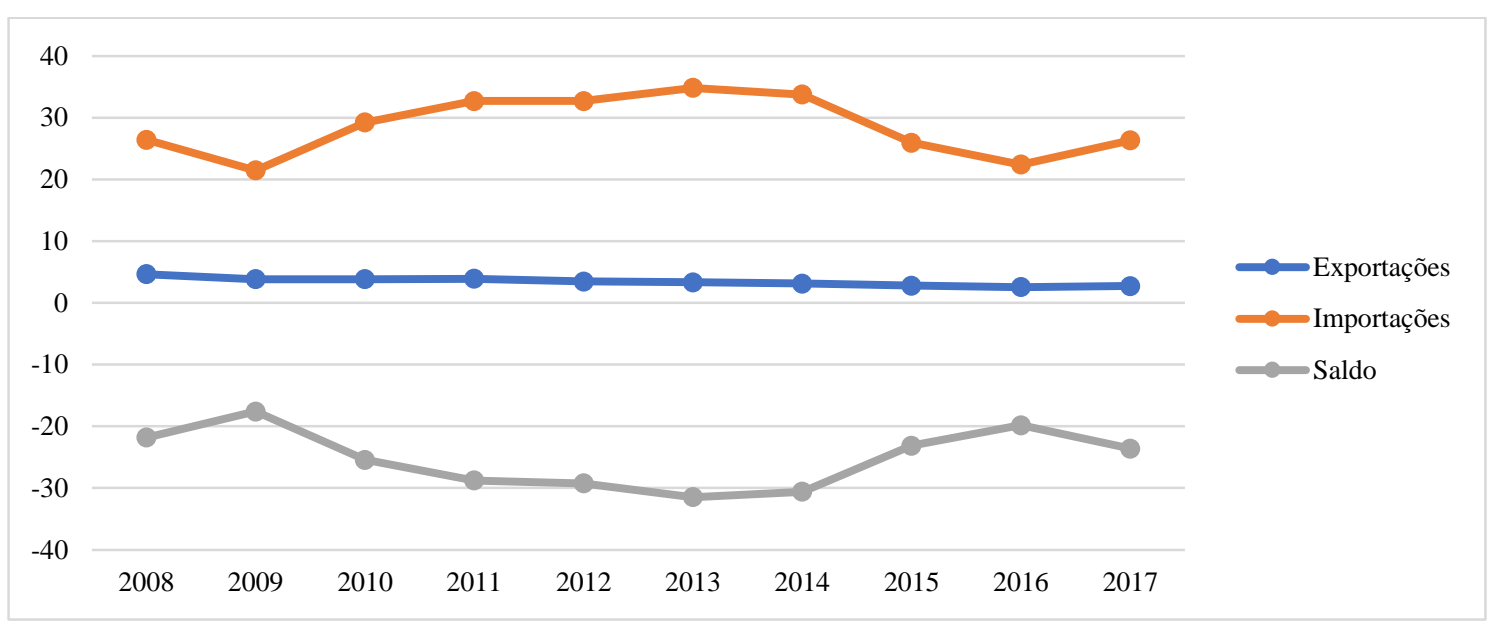

Fonte: MDIC. Elaboração própria. 
Em 2016 as exportações corresponderam a 58\% do valor de 2008, ou seja, entraram em queda livre, enquanto as importações tiveram alta até 2014, com posterior queda, e retomou crescimento em 2017. O saldo comercial é de elevado déficit no período. O menor déficit comercial foi de US\$17,6 bilhões, o que denota problemas da inserção internacional brasileira nesta tipologia.

Dos dois setores levados em consideração, o maior desempenho nas exportações foi registrado por equipamentos de informática, produtos eletrônicos e ópticos com uma média anual de US\$ 2,1 bilhões, mas este mesmo setor apresentou importações com valor anual médio de US\$ 21,6 bilhões. Não é estranho que o seu déficit anual registrado fosse de US\$ 19,5 bilhões. Importante frisar que produtos farmoquímicos e farmacêuticos apresentou seu valor anual médio na mesma direção na magnitude de US\$ 5,6 bilhões.

O estudo de Morceiro e Guilhoto (2019) apresentou análise voltada ao valor adicionado global destes setores e a conclusão é pelo argumento do baixo dinamismo:

Em 2016, o Brasil contribuiu com apenas 0,5\% do valor adicionado global destes setores, enquanto China e Estados Unidos lideraram, respectivamente, com $28,0 \%$ e $21,7 \%$ do total global, conforme informações da UNIDO. Nos países da OCDE, estes setores são responsáveis por bens de alta tecnologia oriundos de elevados investimentos em P\&D e, na China, eles foram utilizados como uma escada na industrialização em curso (Morceiro; Guilhoto, 2019, p. 16).

No gráfico 13 observa-se a evolução do coeficiente de penetração das importações: 


\section{Gráfico 13 - Coeficiente de penetração das importações da indústria de transformação - Alta intensidade tecnológica (preços constantes, em \%)}

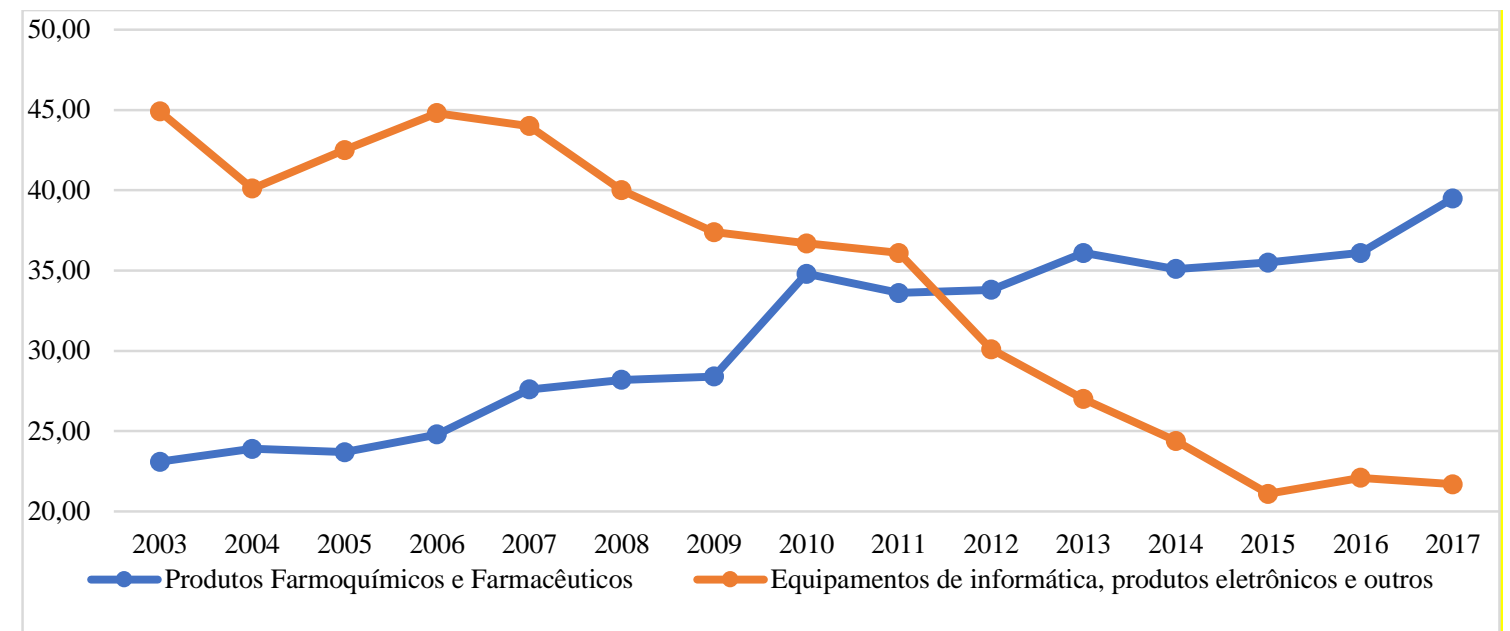

Fonte: CNI. Elaboração própria.

Produtos farmoquímicos e farmacêuticos apresentaram alta no coeficiente de penetração das importações, com crescimento após a crise de 2008. Em 2003 tinha valor de 23,1\%, em $201034,8 \%$ e, em 2017 39,5\%. Aventa-se que o setor de produtos farmoquímicos e farmacêuticos passa por um processo de desindustrialização relativa por substituição do bem final da produção nacional pela importação. O oposto é observado em equipamentos de informática, produtos eletrônicos e outros, pois teve queda no indicador, em 2008 teve 44,9\% e, em 2017, teve $21,7 \%$. Assim, ressalta-se que Brasil apresenta baixa competitividade em setores mais sofisticados. Evidencia-se novamente a importância de uma política industrial que contemple a inovação como o objetivo central (industrialistas), a necessidade de medidas protecionistas (estruturalistas) e o manejo do câmbio (novo-desenvolvimentistas). Contudo, destaca-se a dificuldade com a concorrência internacional nesse setor, sobretudo com a China, pois o Brasil está há décadas em uma situação de falling behind. Morceiro (2019) argumentou que:

O Brasil possui uma dependência tecnológica do exterior de insumos e componentes mais elaborados e sofisticados do ponto de vista da complexidade produtiva em várias indústrias relevantes para o país em termos de potencial tecnológico e emprego de mão de obra qualificada que pagam salários elevados [...] Dessa maneira, as cadeias produtivas que produzem os produtos mais elaborados encontram-se esgarçadas e com encadeamentos intersetoriais fracos. Isso é preocupante para o desenvolvimento socioeconômico nacional em termos de tecnologia, mão de obra, inserção externa e capacidade de suprimento da demanda doméstica (Morceiro, 2019, s.p.). 
Após análise por distintas tipologias, é possível realizar um balanço sobre a desindustrialização relativa, conforme quadro 2 :

\section{Quadro 2 - Síntese dos resultados por intensidade tecnológica ${ }^{\mathrm{A}}$}

\begin{tabular}{|c|c|c|}
\hline $\begin{array}{c}\text { Setores } \\
\text { (Intensidade } \\
\text { Tecnológica) }\end{array}$ & $\begin{array}{l}\text { Taxa de variação percentual } \\
\text { média dos coeficientes de: } \\
\text { - Insumos Importados } \\
\text { - Penetração de } \\
\text { importações A } \\
\end{array}$ & $\begin{array}{c}\text { Sinais mais intensos de } \\
\text { desindustrialização relativa por: }\end{array}$ \\
\hline \multirow{2}{*}{ Baixa } & - 99,8 & \multirow{2}{*}{$\begin{array}{l}\text { Substituição do produto final nacional } \\
\text { pelo produto final importado }\end{array}$} \\
\hline & $\circ \mathbf{1 0 0 , 0}$ & \\
\hline \multirow{2}{*}{ Média-Baixa } & - 37,9 & \multirow{2}{*}{$\begin{array}{l}\text { Substituição do produto final nacional } \\
\text { pelo produto final importado }\end{array}$} \\
\hline & $\circ \mathbf{1 3 1 , 4}$ & \\
\hline \multirow{2}{*}{ Média-Alta } & - 63,4 & \multirow{2}{*}{ Redução do conteúdo nacional } \\
\hline & $\circ 55,9$ & \\
\hline \multirow{2}{*}{ Alta } & - 25,2 & \multirow{2}{*}{ Redução do conteúdo nacional } \\
\hline & o $-9,02$ & \\
\hline
\end{tabular}

Fonte: Elaboração Própria.

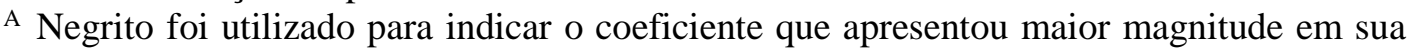
variação percentual média. A partir disso, a desindustrialização relativa foi considerada mais intensa através do coeficiente que mostrou a variação positiva com maior proeminência.

\section{Considerações finais}

A partir dos resultados explicitam-se considerações sobre o processo de desindustrialização no Brasil:

i) Baixa intensidade tecnológica - apresenta sinais de desindustrialização relativa por quebra de elos em cadeias produtivas e por substituição do produto final nacional pelo produto final importado. Importante ressaltar que a variação percentual média de ambos os coeficientes utilizados demonstrou magnitudes elevadas como demonstrado no quadro 2. A despeito disso, o cenário externo neste segmento demonstra ainda ter certo grau de competitividade.

ii) Média-baixa intensidade tecnológica - os indicadores e dados apresentam sinais de desindustrialização relativa nos dois formatos estudados. Se considerarmos como proxy para a intensidade dos sinais a variação percentual média dos coeficientes, o processo se mostra com maior magnitude na desindustrialização relativa por substituição do produto final nacional pelo produto final importado. A exceção cabe ao setor de coque, produtos derivados do petróleo e biocombustíveis, 
pois não parece sofrer quebra de elos. Em MBIT as taxas de variação da produção física foram, em média, negativas. Em relação ao setor externo, apresentou resultados inferiores aos de BIT, porém com capacidade de recuperação.

iii) Média-alta intensidade - apresentam sinais de desindustrialização nos dois formatos listados. Porém, os indicadores principais utilizados para proxy dessa mensuração apresentam valores elevados desde o início do período levado em consideração para a análise. Reforçam argumentos de desindustrialização nesta tipologia já que está claro o fraco desempenho da produção física e por ter, por outro lado, o mais elevado déficit no saldo da balança comercial industrial. A taxa de variação percentual média se mostrou mais abrupta no coeficiente de insumos importados, o que denota que a desindustrialização relativa por redução do conteúdo nacional seja mais abrupta.

iv) Alta intensidade tecnológica - existem indícios de que esses setores passam por desindustrialização por quebra de elos ao longo de suas respectivas cadeias produtivas. Todavia, apenas o setor de produtos farmoquímicos e farmacêuticos apresenta sinais de desindustrialização por substituição do produto nacional final pelo importado. O desempenho da produção física é frágil e apresenta saldo da balança comercial negativa, com elevada necessidade de importações para a produção.

Após avaliação de dados e indicadores por intensidade tecnológica, é possível dizer que, de maneira geral, a desindustrialização relativa, de distintas maneiras, afeta a indústria de transformação brasileira. Contudo há variações por setor e por intensidade tecnológica, sendo que as consequências refletidas no saldo da balança comercial e na taxa de variação média da produção física são mais graves em MAIT e AIT. A partir disso, é possível verificar que os maiores desafios para a reversão do processo, inevitavelmente passarão por esforços que busquem dinamizar setores mais intensivos em tecnologia, utilizando-se de políticas industriais ativas e ajustes na política macroeconômica.

Por fim, pode-se concluir que as vertentes de pensamento apresentadas na seção 2 foram de grande importância nas análises dos dados trazidos nas demais seções. No entanto, pode-se concluir de maneira sintética que: i) a vertente ortodoxa possui baixo poder de explicação dos dados que foram considerados a partir de seu arcabouço teórico. ii) As três vertentes heterodoxas (novo desenvolvimentismo, industrialistas e estruturalistas) possuem, em suas 
constatações, importantes recomendações para o combate a desindustrialização, com maior robustez teórica, o que nos permite analisar de maneira relativamente satisfatória os dados apresentados a partir da seção 3. Todavia, nenhuma delas, de maneira separada, possui um arcabouço de teórico suficiente para explicar a desindustrialização no Brasil, haja vista o caráter dinâmico, complexo e multiformato em que o processo apresenta sinais de ocorrência.

\section{Referências}

ALMEIDA, F. Estratégias, capacidades organizacionais e desempenho da indústria têxtil brasileira. 2014. 267 p. Tese (Doutorado em Gestão de Empresas) - Faculdade de Economia, Universidade de Coimbra, Coimbra, 2014. Disponível em: http://hdl.handle.net/10316/27156. Acesso em 12 set. 2021.

ARAUJO, E.; MARCONI, N. Estrutura produtiva e comércio exterior no Brasil: uma investigação sobre as elasticidades-renda da demanda por exportações e importações setoriais. IN: MARCONI, N.; BARBOSA, N.; PINHEIRO, M.; CARVALHO, L. (org.). Indústria e Desenvolvimento Produtivo no Brasil. Rio de Janeiro: Elsevier, 2015.

AREND, M.; FONSECA, P. 25 anos de catching up, 25 anos de falling behind. Revista de Economia Política, v. 32, n. 1, p. 33-54, 2012.

BACHA, E; BONELLI, R. Uma interpretação das causas da desaceleração econômica do Brasil. Revista de Economia Política, v. 25, n. 3, p. 163-189, 2005.

BACHA, E.; DE BOLLE, M. O futuro da indústria no Brasil: a desindustrialização em debate. Rio de Janeiro: Civilização Brasileira, 2013.

BONELLI, R. Industrialização e desenvolvimento: notas e conjecturas com foco na experiência do Brasil. Seminário Industrialização, Desindustrialização e Desenvolvimento. Trabalho apresentado no Seminário Industrialização, Desindustrialização e Desenvolvimento. São Paulo: FIESP; IEDI, 28 nov. 2005.

BONELLI, R.; PESSOA, S.; MATOS, S. Desindustrialização no Brasil: fatos e interpretação. IN: BACHA, E.; DE BOLLE, M. B. (Orgs). O futuro da indústria no Brasil: a desindustrialização em debate. Rio de Janeiro: Civilização Brasileira, 2013.

BRESSER PEREIRA, L. C. Reflexões sobre o novo desenvolvimentismo e o desenvolvimentismo clássico. Revista de Economia Política, v. 36, n. 2, p. 237 $265,2016$. 
BRESSER-PEREIRA, L. C. Em busca do desenvolvimento perdido: um projeto novo-desenvolvimentista para o Brasil. Rio de Janeiro: FGV Editora, 2018.

BRESSER-PEREIRA, L. C.; MARCONI, N.; OREIRO, J. L. Doença holandesa. IN: BRESSER-PEREIRA, L. C.; MARCONI, N.; OREIRO, J.L. Macroeconomia desenvolvimentista: teoria e política econômica do novo-desenvolvimentismo. Rio de Janeiro: Campus/Elsevier, 2015.

CANO, W. (Des)industrialização e (sub)desenvolvimento. Cadernos do Desenvolvimento, v. 9, n. 15, p. 139-174, 2014.

CARNEIRO, R. Impasses do desenvolvimento brasileiro: a questão produtiva. Textos para discussão IE/Unicamp, n. 153. Campinas: Unicamp, 2008.

CASARIN, R. Consumo decepciona e produção do setor têxtil fica estagnada em 2018. Jornal DCI, 12 nov. 2018. Disponível em: http://monitoramento.spmj.com.br/noticias/wpcontent/uploads/sites/4/2018/11/Capturar9.jpg. Acesso em: 12 set. 2021.

CASSIOLATO, J. Que futuro para a indústria brasileira. IN: MDIC - Ministério do Desenvolvimento, Indústria e Comércio Exterior; IEL - Instituto Euvaldo Lodi (Orgs.). O futuro da indústria, oportunidades e desafios: a reflexão da universidade. Brasília: MDIC/IEL Nacional, 2001.

CASSIOLATO, J.; LASTRES, H. Celso Furtado e os dilemas da indústria e inovação no Brasil. Cadernos do Desenvolvimento, v. 10, n. 17, p. 188-213, 2015.

CHIARINI, T.; SILVA, A. Comércio exterior brasileiro de acordo com a intensidade tecnológica dos setores industriais: notas sobre as décadas de 1990 e 2000. Nova Economia, v. 26, n. 3, p. 1007-1051, 2016.

CNI - CONFEDERAÇÃO NACIONAL DA INDÚSTRIA. Coeficientes de Abertura Comercial (Metodologia). Brasília: CNI, 2016.

COLOMBO, A. Desindustrialização brasileira em perspectiva: linhas de pensamento, formatos e dinâmica setorial. 133 p. Dissertação (Mestrado em Teoria Econômica) - Centro de Ciências Jurídicas e Econômicas, Universidade Federal do Espírito Santo, Vitória, 2019.

COLOMBO, A.; FELIPE, E.; SAMPAIO, D. A desindustrialização no Brasil: um processo, várias vertentes. Revista de Economia da UEG, v. 16, n. 1, p. 81-106, 2020 . 
DINIZ, C. Expansão asiática, corrida científica e tecnológica mundial, desindustrialização no Brasil. Texto para Discussão CEDEPLAR n. 565, 2017.

FERRAZ, L.; GUTIERRE, L.; CABRAL, R. A indústria brasileira na era das cadeias globais de valor. In: BARBOSA, N.; MARCONI, N.; PINHEIRO, M. CARVALHO, L. (Orgs.). Indústria e desenvolvimento produtivo no Brasil. Rio de Janeiro: Elsevier, 2015.

FURTADO, C. Desarollo e subdesarollo. In: BIELSCHOWSKY, R. (Org.) Cinqüenta años de pensamiento en la Cepal: textos seleccionados, Volume 1. Santiago: Cepal/Fondo de Cultura Económica, 1998.

KUPFER, D. Não há consenso entre os economistas sobre a desindustrialização do País. Entrevista concedida a Raquel Landim. O Estado de São Paulo, 12 nov. 2009. Disponível em: https://www.estadao.com.br/noticias/geral,nao-haconsenso-entre-os-economistas-sobre-a-desindustrializacao-do-pais, 465047.

Acesso em: 09 nov. 2018.

KUPFER, D. Ausência de coesão política impede projeto de desenvolvimento brasileiro. Entrevista concedida a Patrícia Fachin. IHU-Online, 25 mar. 2015. Disponível em: http://www.ihu.unisinos.br/entrevistas/o-atual-hiato-muitoprovavelmente-sera-resolvido-a-brasileira-entrevista-especial-com-davidkupfer/541188-o-atual-hiato-muito-provavelmente-sera-resolvido-a-brasileiraentrevista-especial-com-david-kupfer. Acesso em 15 abr 2020.

KUPFER, D. A indústria ainda é aquela. Fundação Astrojildo Pereira, s.p., 11 out 2016. http://www.fundacaoastrojildo.com.br/2015/2016/10/11/david-kupfer-aindustria-ainda-e-aquela/. Acesso em 15 abr. 2020.

MARCONI, N. A taxa de câmbio e o processo de crescimento econômico em países de renda média. COFECON-Conselho Federal de Economia, 21 jan. 2020. Disponível em: https://www.cofecon.org.br/2020/01/21/artigo-a-taxa-de-cambioe-o-processo-de-crescimento-economico-em-paises-de-renda-media/. Acesso em 12 set. 2021.

MORCEIRO, P. Desindustrialização na economia brasileira no período 20002011: abordagem e indicadores. São Paulo: Cultura Acadêmica, 2012.

MORCEIRO, P. A indústria brasileira no limiar do século XXI: uma análise da sua evolução estrutural, comercial e tecnológica. 2018. 216 p. Tese (Doutorado em Economia das Instituições e do Desenvolvimento) - Faculdade de Economia, Administração e Contabilidade Economia do Desenvolvimento, Universidade de São Paulo, São Paulo, 2018. 
MORCEIRO, P. 60 segmentos industriais que mais importam insumos e componentes. Valor Adicionado, 6 mar. 2019. Disponível em: https://valoradicionado.wordpress.com/2019/03/06/60-segmentos-industriaisque-mais-importam-insumos-e-componentes/. Acesso em: 25 março 2019.

MORCEIRO, P.; GUILHOTO, J. Desindustrialização setorial no Brasil. São Paulo: Instituto de Estudos para o Desenvolvimento Industrial (IEDI), 2019.

MOREIRA, M. Indústria têxtil prevê retomada de crescimento só em 2016. Agência Brasil, 22 jan. 2015. Disponível em: http://agenciabrasil.ebc.com.br/economia/noticia/2015-01/industria-textil-preveretomada-de-crescimento-so-em-2016. Acesso em 20 fev. 2019.

OREIRO, J. L. Macroeconomia do desenvolvimento: uma perspectiva keynesiana. Rio de Janeiro: LTC, 2016.

OREIRO, J. L; FEIJÓ, C. Desindustrialização: conceitos, causas, efeitos e o caso brasileiro. Revista de Economia Política, v. 30, n. 2, p. 219-232, 2010.

RICUPERO, R. Câmbio mata. Folha de São Paulo, 09 mai. 2010. Disponível em: http://www1.folha.uol.com.br/fsp/dinheiro/fi0905201004.htm. Acesso em 23 out. 2018.

SAMPAIO, D. Desindustrialização e estruturas produtivas regionais no Brasil. 2015. 234 p. Tese (Doutorado em Desenvolvimento Econômico) - Instituto de Economia, Universidade Estadual de Campinas, 2015.

SARTI, F.; HIRATUKA, C. Desenvolvimento industrial no Brasil: oportunidades e desafios futuros. Textos para discussão IE/UNICAMP n. 187. Campinas: Unicamp, 2011.

SARTI, F.; HIRATUKA, C. Desempenho recente da indústria brasileira no contexto de mudanças estruturais domésticas e globais. IN: CARNEIRO, R.; BALTAR, P.; SARTI, F. (Orgs.). Para além da política econômica. São Paulo: Editora Unesp Digital, 2018.

SCHWARTSMAN, A. Uma tese com substâncias. Folha de São Paulo, 19 ago. 2009.

Disponível

em: https://www1.folha.uol.com.br/fsp/dinheiro/fi1908200909.htm. Acesso em 12 set. 2021.

SILVEIRA, M.; ANGELI, E.; SALOMÃO, I. Complexidade, (des)industrialização e novo-desenvolvimentismo: interseções teóricas. Pesquisa \& Debate, v. 31, n. 2, p. 58-80, 2019. 